\title{
Long-term monitoring of soil management effects on runoff and soil erosion in sloping vineyards in Alto Monferrato (North-West Italy).
}

\author{
Marcella Biddoccua, , Stefano Ferraris ${ }^{\mathrm{b}}$, Francesca Opsi ${ }^{\mathrm{a}}$, \\ Eugenio Cavalloa
}

aInstitute for Agricultural and Earthmoving Machines (IMAMOTER), National Research Council of Italy (CNR), 10135 Torino, Strada delle Cacce, 73, Italy

bInteruniversity Department of Regional and Urban Studies and Planning (DIST), Politecnico di Torino and Università di Torino, 10125 Torino, Castello del Valentino, viale Mattioli, 39, Italy

\section{Abstract}

Long-term runoff and soil erosion data have been collected from differently managed fieldscale vineyard plots within the "Tenuta Cannona Experimental Vine and Wine Centre of Regione Piemonte", located in the Alto Monferrato vine production area (NW Italy). The primary intent of the program was to evaluate the effects of agricultural management practices on the hydrologic, soil erosion, nutrient transport and soil compaction processes in vineyards. Field runoff data have been collected for every event since the year 2000 until now. Sediment and nutrient concentrations in water have been also monitored. Regarding soil properties and initial conditions, surveys have been carried out to investigate spatial and temporal variability of soil bulk density, soil saturated conductivity, soil water content, and penetration resistance. The Cannona Data Base (CDB) includes data for more than 300 runoff events and over 90 soil loss events; moreover, periodic measurements for soil physical characteristics are included for the three plots.

Runoff and sediment yield showed high annual and seasonal variability and were strongly affected by the adoption of different soil management in the vineyard inter-rows, especially after some years of observation. Grass cover reduced runoff by at least $37 \%$, in comparison with management by tillage, and average annual sediment yield ranged from $1.8 \mathrm{Mg} \mathrm{ha}^{-1}$ year-1 to $20.7 \mathrm{Mg} \mathrm{ha}^{-1}$ year-1, respectively for the "grass covered" and the "reduced tillage" vineyards. Furthermore, results showed the effect of the adopted soil management on soil properties. The Cannona Data base (CDB) can be accessed via a website (http://sustag.to.cnr.it/index.php/cannona-db) supported by the IMAMOTER-CNR. 
Postprint version of:

Biddoccu et al., 2016. Long-term monitoring of soil management effects on runoff and soil erosion in sloping vineyards in Alto Monferrato (North-West Italy). Soil Till. Res., 155 (2016), pp. 176-189.

https://doi.org/10.1016/j.still.2015.07.005

Key words: soil management; vineyards; runoff; soil erosion; soil compaction; database.

\section{Introduction}

Piemonte, NW Italy, is a long established and specialized wine region and produces some of the best-known, top quality Italian wines (e.g. Asti Spumante, Barolo, Barbera) and it is the second largest (after Veneto) Italian wine exporting region. In Piemonte the vine growing and oenological industry greatly contribute to the agricultural income and vineyards cover more than 52,000 hectares, accounting for around to $7.3 \%$ of the Italian wine production area $(725,267$ hectares) (ISTAT, 2014). According to the agricultural statistical database of the Piemonte Regional Administration (Regione Piemonte, 2014a), more than 95\% of the vineyard surface of the region is on hilly area and near $1 \%$ on mountain area, and the vineyards are concentrated in the southern part of the region, in the hilly territory Provinces of Asti, Cuneo and Alessandria. Hilly vineyards are easily subject to soil erosion, depending on the adopted soil management system. Water and soil protection are key issues for European countries, as the European Commission demonstrated by adopting the Water Framework Directive in 2000 (Directive 2000/60/EC) and the Soil Thematic Strategy in 2006 (CEC, 2006a; CEC, 2006b). Erosion has been identified as one of the major threats that affect European agricultural soils. An estimated $12 \%$ of Europe's total land area is subject to water erosion. Cerdan et al. (2010) estimated a mean erosion rate of $2.3 \mathrm{t} \mathrm{ha}^{-1}$ year $^{-1}$ for Italy, corresponding to $12.5 \%$ of the total European erosion. They predicted the highest erosion rates in vineyards and arable lands. Measured data (Maetens et al., 2012) showed that in the Mediterranean region runoff rates higher than $9 \%$ are related to vineyard land use. Among agricultural uses only tree crops showed higher runoff rates in the same region. More than $50 \%$ of the hills of the Piemonte region (NW Italy) is characterized by soils with moderately high or high erodibility, with values of the RUSLE K-factor (Wischmeier and Smith, 1978) higher than $0.047 \mathrm{Mg}$ ha h ha-1 $\mathrm{MJ}^{-1} \mathrm{~mm}^{-1}$ (Ipla, 2007; van der Knijff et al., 2000). In Piemonte, Tropeano (1984) ran the first soil erosion measurements in vineyards in the 1980's, for about 2 years. In some vineyards located in the Alto Monferrato area, Tropeano measured soil losses ranging from $0.2 \mathrm{Mg} \mathrm{ha}^{-1}$, in a vineyard where dry agents were used in no-tilled inter-rows, to $47.4 \mathrm{Mg} \mathrm{ha}^{-1}$ in a deeply ploughed vineyard. In 2007 the Regional Rural Development programme introduced environmental payments to encourage the adoption of best soil management practices, i.e. the use of grass cover in vineyards and orchards in order to protect soil from degradation. In recent years several studies have been 
Postprint version of:

Biddoccu et al., 2016. Long-term monitoring of soil management effects on runoff and soil erosion in sloping vineyards in Alto Monferrato (North-West Italy). Soil Till. Res., 155 (2016), pp. 176-189.

https://doi.org/10.1016/j.still.2015.07.005

carried out across Europe in order to evaluate the effect of vineyard's soil management on water and soil losses, with measurements both under simulated (Arnaez et al., 2007; Blavet et al., 2009) and under natural rainfall (Raclot et al., 2009; Novara et al., 2011; RuizColmenero et al., 2011). Experiments under natural rainfall are usually based on data collected during a monitoring period ranging from two to five years. Data collection on a wider temporal scale allow a better assessment of the temporal variability of water and soil losses. In fact, hydrological and soil erosion response can be very different from one year to another one (Casalí et al., 2008), and with the exception of extraordinary erosive rainfall events, erosion shows visible effects only after a few years. Furthermore, once they are established, vineyards are cultivated for some decades. In order to evaluate the long-term effects of agricultural management practices on the hydrologic system, soil erosion, and soil compaction processes in vineyards, the Institute for Agricultural and Earthmoving Machines (IMAMOTER) of the National Research Council of Italy (CNR) initiated a research program in the "Tenuta Cannona Experimental Vine and Wine Centre of Regione Piemonte" (Tenuta Cannona Centre) in 2000, with support of the Office for Agricultural Development of Regione Piemonte. The experiment consists of monitoring natural rainfall events producing runoff and erosion on three field-size vineyard plots with different soil management. In addition, recurrent measurements have been carried out to investigate spatial and temporal variability of the soil bulk density, soil water content, and penetration resistance. The Cannona Erosion Plots are representative of a real vineyard, since every plot is a hillslope portion of a vineyard field, that is managed according to traditional farming practices, with different inter-row's soil management. Data from 10 years of observation were analyzed and previously reported in order to evaluate the effect of soil management and seasons on runoff and soil erosion processes in sloping vineyards (Corti et al., 2011; Biddoccu et al., 2013; Biddoccu et al., 2014). The monitoring activities at the Tenuta Cannona Experimental Centre are currently carried out and implemented in order to improve the understanding of the soil management effects on soil hydrology, erosion, and compaction in sloping vineyards. Other natural processes are strictly related to the hydrologic behavior of the soil that drives infiltration, runoff formation on slopes, soil erosion, and the consequent sediment delivery to water courses. Costantini and Lorenzetti (2013) underlined the need of better understanding of soil degradation processes in a multi-disciplinary approach, with particular regard to Italy, due to the great variability of environmental conditions. 
Postprint version of:

Biddoccu et al., 2016. Long-term monitoring of soil management effects on runoff and soil erosion in sloping vineyards in Alto Monferrato (North-West Italy). Soil Till. Res., 155 (2016), pp. 176-189.

https://doi.org/10.1016/j.still.2015.07.005

The aim of this paper is to provide a description of the Tenuta Cannona Erosion Plots and of the Cannona Data Base (CDB), and to present the main results of the 14-years runoff and sediment losses monitoring. The CDB represents a data collection which is unique in Italy for vineyards, showing the long-term response of soil to natural rainfall in terms of runoff and soil erosion during more than a decade of experimentation. It includes data for more than 300 runoff events and over 90 soil loss events, and data of some soil physical characteristics monitored in the plots. Instrumentation and methods used in data collection and analysis are described in the following paragraphs. The CDB is available on a website supported by the CNR, for water and land management researchers and professionals. Data from the CDB are available to calibrate and validate both runoff and soil erosion models. Also, it allows to investigate the interactions between land use, soil management, and natural processes at different scales.

\section{Materials and methods}

\subsection{Site description}

The "Tenuta Cannona Experimental Vine and Wine Centre of Regione Piemonte" (44 $40^{\circ}$ $\mathrm{N}, 8^{\circ} 37^{\prime} \mathrm{E}, 296 \mathrm{~m}$ asl) is located in the municipality of Carpeneto (AL), $85 \mathrm{~km}$ south-east of Torino, Northern Italy (Fig.1). The experimental site is located in the Orba watershed, within the southern part of the Tanaro basin; the area belongs to the Alto Monferrato hilly region, which is a valuable vine-growing and DOC wine production area. The Cannona vineyards lie on Pleistocenic fluvial terraces in the Tertiary Piedmont Basin, including highly altered gravel, sand and silty-clay deposits, with red alteration products (Carta Geologica d'Italia, scala 1:100.000, Foglio 70). The soils derived from reworked Pleistocene alluvium, have a clay to clay-loam texture. The climate is sublitoranean, with an average annual precipitation of $965 \mathrm{~mm}$ at the Ovada (187 m asl) weather station (1951-1990), mainly concentrated in Autumn (October and November) and Spring (March). The driest month was July. The mean annual temperature measured at Alessandria (96 $\mathrm{m}$ asl) during the same period of observation was $12.6^{\circ} \mathrm{C}$ (Biancotti et al. 1998). Mean annual air temperature measured at the experimental site in the period $2000-2013$ was $13^{\circ} \mathrm{C}$ and the average annual precipitation was $849 \mathrm{~mm}$. 
Postprint version of:

Biddoccu et al., 2016. Long-term monitoring of soil management effects on runoff and soil erosion in sloping vineyards in Alto Monferrato (North-West Italy). Soil Till. Res., 155 (2016), pp. 176-189.

https://doi.org/10.1016/j.still.2015.07.005

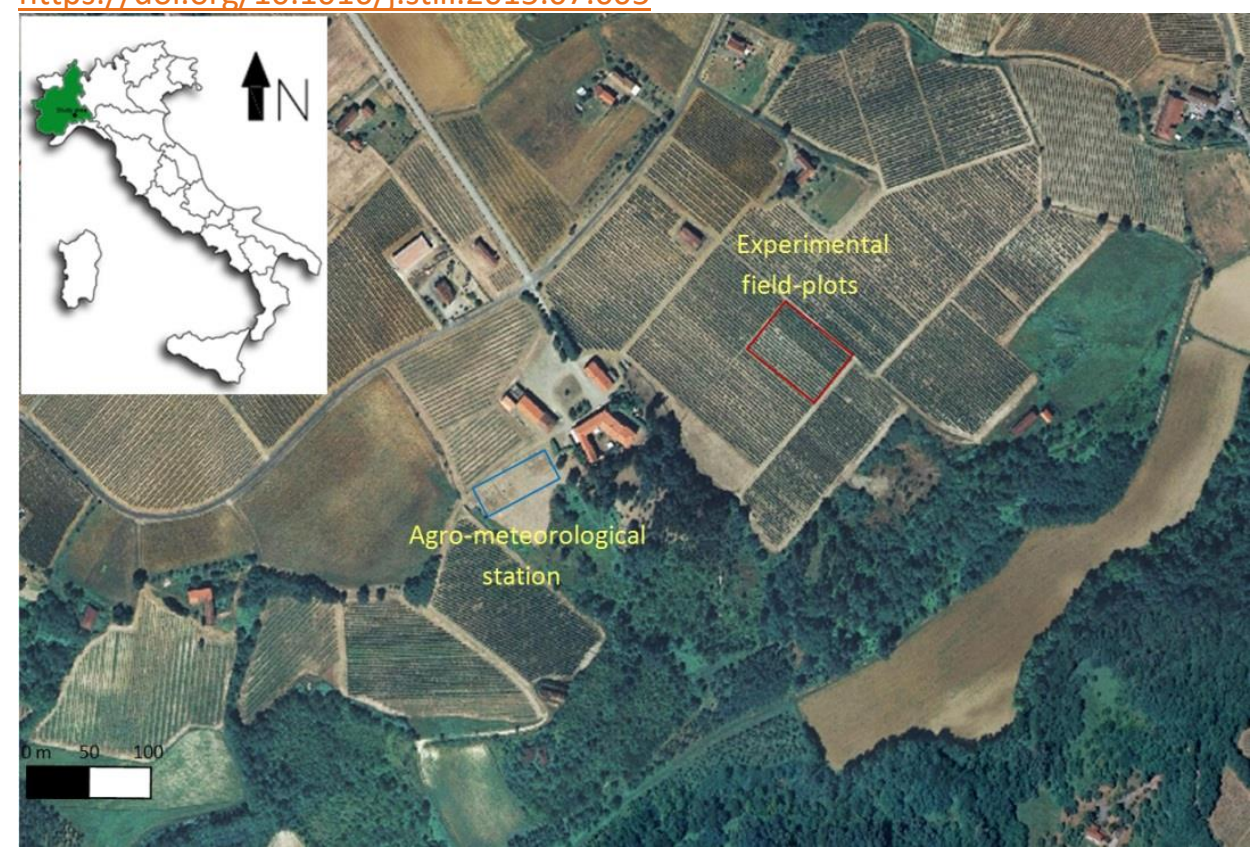

Fig.1. Location of the Tenuta Cannona Experimental Centre. Rectangles show the experimental field plots and of the Agro-meteorological station.

\subsection{The experimental plots}

The three experimental vineyard plots (Fig.2) are part of a larger vineyard, that was planted in 1988 with Barbera vines, managed in according to conventional farming for wine production. Each plot is $1221 \mathrm{~m}^{2}$ (74 $\mathrm{m}$ long and $16.5 \mathrm{~m}$ wide). The three plots lie adjacent to each other on a hillslope with SE aspect and average gradient of $15 \%$. Soil is classified as Typic Ustorthents, fine-loamy, mixed, calcareous, mesic (Soil Survey Staff, 2010) or Dystric Cambisols (FAO/ISRIC/ISSS, 1998). 


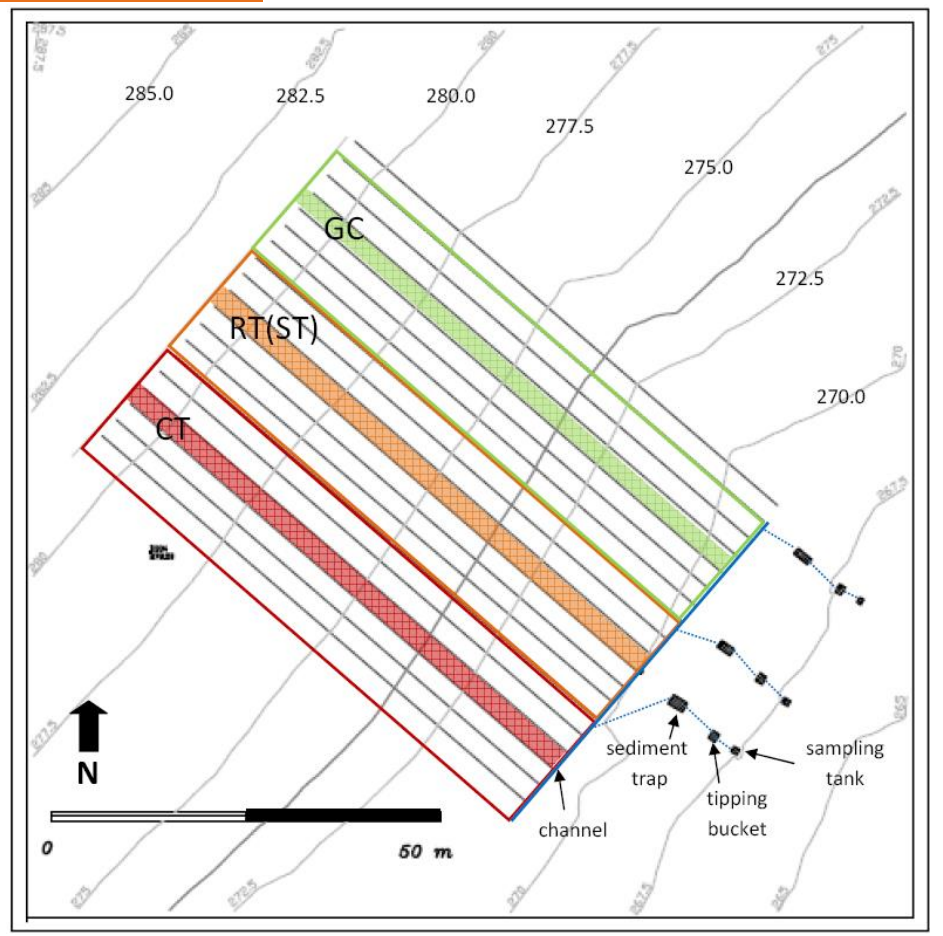

Fig.2. Sketch of the three vineyard erosion plots and the runoff collection/measuring system. Since 2000, the plots have been managed with conventional tillage (CT), reduced tillage (RT), converted in conventional tillage with grass strip, ST, in 2012, and grass cover (GC). The coloured inter-rows are those where SWC measurements and sampling are carried out.

Each plot includes 7 vine rows aligned along the slope, where the vines are spaced $1.0 \mathrm{~m}$ along the row and $2.75 \mathrm{~m}$ between the rows. Since 2000, different cultivation techniques have been adopted on the soil between the vine rows of the 3 plots: the first plot has been managed with conventional tillage (CT, processed with chisel at a depth of about $0.25 \mathrm{~m}$ ), in the second plot reduced tillage has been used (RT, with rotary cultivator to a depth of 0.15 $\mathrm{m}$ ), and in the third plot controlled grass cover has been adopted (GC, with spontaneous grass controlled with mulcher during the year). In Autumn 2011, the inter-rows of this plot were tilled and a grass mixture was sown, to renew the grass cover. The grass mixture was composed by: Lolium perenne $20 \%$, Festuca rubra $60 \%$, Poa nemoralis $15 \%$, Poa trivialis $5 \%$. Since 2012, the soil management with reduced tillage (RT) has been abandoned and replaced with conventional tillage with a 10-meters wide grassed strip at the bottom of each inter-row (ST). Tillage (in CT and RT(ST)) and grass mulching (in GC) were usually carried out twice a year, in spring and autumn, or in spring and summer. Weeds under the rows of the three plots are controlled with a single herbicide application (Glifosate $\AA$ ) in spring, for a width of about $0.6 \mathrm{~m}$ across the vine row. Chemical fertilizer was applied in the vineyard until 2004 , by distributing once per year (in spring or autumn) the equivalent of $30 \mathrm{~kg} \mathrm{ha}^{-1}$ of $\mathrm{N}$, 
Postprint version of:

Biddoccu et al., 2016. Long-term monitoring of soil management effects on runoff and soil erosion in sloping vineyards in Alto Monferrato (North-West Italy). Soil Till. Res., 155 (2016), pp. 176-189.

https://doi.org/10.1016/j.still.2015.07.005

$20 \mathrm{~kg} \mathrm{ha}{ }^{-1}$ of $\mathrm{P}$ and $45 \mathrm{~kg} \mathrm{ha}^{-1}$ of $\mathrm{K}$ in form of complex fertilizers. The calendar with description of the soil management operations is available in the database (CANNONA_MGMT.txt).

\subsection{Climate data}

Since 1998 meteorological data have been collected by means of an agro-meteorological station placed at about $200 \mathrm{~m}$ from the plots, within the Tenuta Cannona Centre. Rainfall, air temperature and air relative humidity have been continuously measured and recorded by means of mechanical instruments. Since 2003 data have been also measured by electromechanical station that is included in the RAM (Agro-meteorological Regional Network). Daily and hourly data are available from the "Banca Dati Agrometeorologica" of Regione Piemonte at http://www.sistemapiemonte.it/cms/privati/agricoltura/servizi/378-ram-bancadati-agrometeorologica-consultazione-dati-giornalieri-dati-storici-statistiche

(Regione Piemonte, 2014b). Another automatic weather station was set up in 1992, which is included in the RAN (National Agro-meteorological Network) (MiPAF, 2015). It measures and records data of soil temperature, air temperature and humidity, precipitation, wind direction and speed, leaf wetness, solar radiation, atmospheric pressure, and evapotranspiration. Details on the stations and daily, decadal, and monthly data from 2003 to 2013 were obtained by the "Banca Dati Agrometeorologica Nazionale"(MiPAF, 2014).

Data from the three stations were used to obtain rainfall characteristics for events producing runoff and soil erosion (see following paragraphs).

A meteorological station of the Regional Agency for the Protection of the Environment (ARPA) network is located at Ovada $(A L)$, about $4 \mathrm{~km}$ from the experimental plots. At this site rainfall has been monitored with a 10 min interval since 2000.

\subsection{Runoff}

Each plot was hydraulically bounded: a channel at the top of the plots collects upstream water and there was no surface lateral flow between contiguous inter-rows, since the overland flow was along the main slope direction. Runoff and sediments were collected at the bottom of each plot by a channel, which was connected to a sedimentation trap and then to a tipping bucket device to measure the discharge of runoff (Fig.3). Tipping bucket devices were calibrated to measure runoff with resolution of $0.1 \mathrm{~mm} \mathrm{tip}^{-1}$ and total runoff was obtained by means of analogical counters after each rainfall event producing runoff. In 2011 , electro-magnetic counters were installed to obtain hourly data of runoff volumes, which are 
Postprint version of:

Biddoccu et al., 2016. Long-term monitoring of soil management effects on runoff and soil erosion in sloping vineyards in Alto Monferrato (North-West Italy). Soil Till. Res., 155 (2016), pp. 176-189.

https://doi.org/10.1016/j.still.2015.07.005

available on the website. A portion of the runoff-sediment mixture was sampled for each tip and was collected in a sample tank.
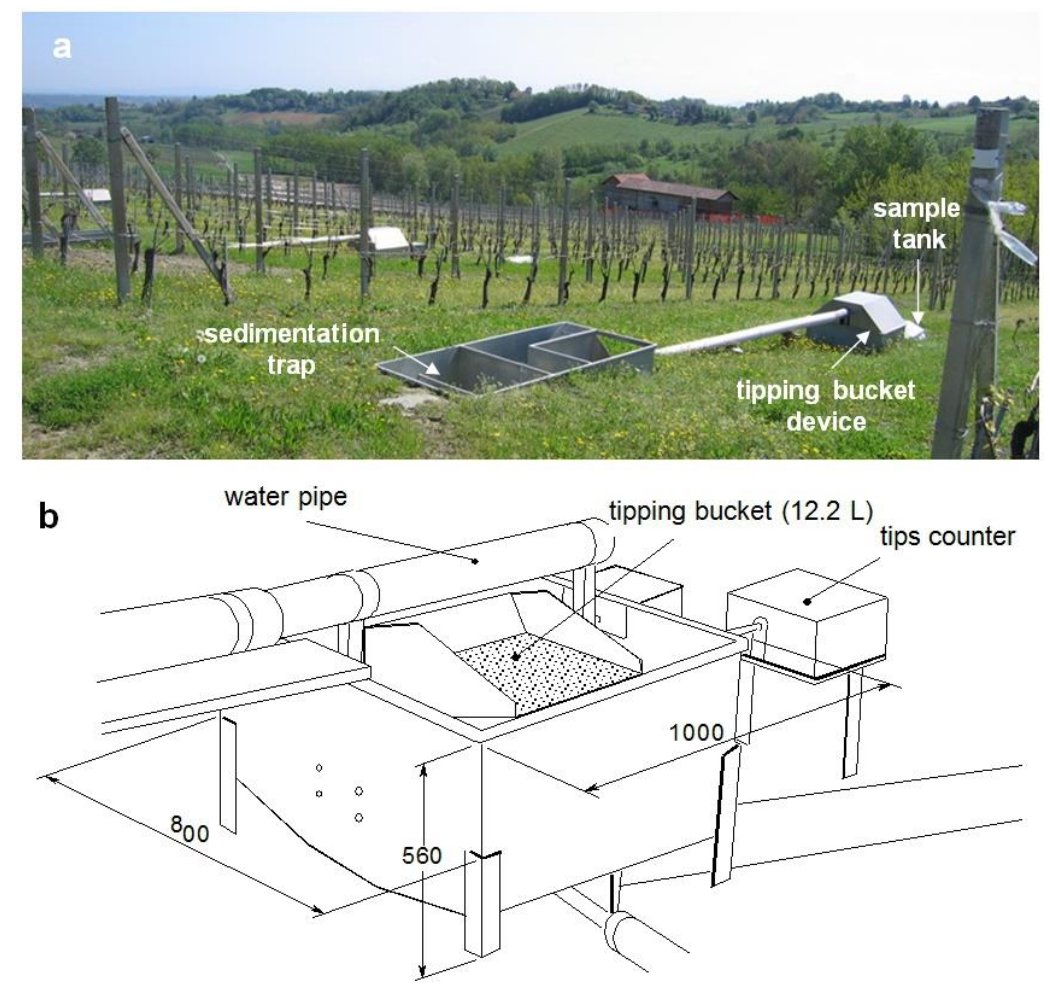

Fig.3. The runoff collection/measuring system (3a) and the tipping bucket measurement device (3b).

Rainfall characteristics were calculated from the data recorded by the agro-meterological stations for each rainfall event. For rainfall events of long duration and low intensity and snowfall events, which occurred in autumn and winter and rarely in early spring, each recorded event included days with precipitation and the following days with runoff measurements due to drainage flow. Snowfall events were considered in cases where they were followed by rain that caused snow melting. In such occasions, snow and rain contributed to produce runoff and, occasionally, to generate soil erosion. Each precipitation event was considered responsible for the amount of runoff and sediment yield that was measured during rainy days and immediately after them.

The runoff events dataset (CANNONA_RUNOFF.txt) includes the following rainfall and runoff variables as description as each runoff event: $I$ ) duration of each meteorological event (D_Ev, h), that was calculated as previously described; ii) duration of rainfall within each event of precipitation ( $\left.\mathrm{D} \_\mathrm{R}, \mathrm{h}\right)$; iii) rainfall depth $(\mathrm{R}, \mathrm{mm})$; iv) maximum rainfall intensity over a 60 -min period $\left(\mathrm{I}_{60}, \mathrm{~mm} \mathrm{~h}^{-1}\right) ; v$ ) mean rainfall intensity, obtained as the ratio between $\mathrm{R}$ and D_R (Im, $\left.\mathrm{mm} \mathrm{h}^{-1}\right)$ vi) runoff measured in each plot (RO, in $\left.\mathrm{mm}\right)$; vi) source of data used to 
Postprint version of:

Biddoccu et al., 2016. Long-term monitoring of soil management effects on runoff and soil erosion in sloping vineyards in Alto Monferrato (North-West Italy). Soil Till. Res., 155 (2016), pp. 176-189.

https://doi.org/10.1016/j.still.2015.07.005

obtain the rainfall variables (Station). Since 2011, hourly and daily rainfall data and runoff volumes were made available in raw format through the "Real-time runoff" section of the CDB website. Daily measurements can be obtained by selecting a period of observation from the web interface. Hourly data can be accessed by selecting a single day. Since August 2013, rainfall data are recorded every 10 minutes. All data available from this web-page are provisional and subject to validation process.

\subsection{Soil and nutrient losses}

After each erosive event, a $1.5 \mathrm{~L}$ sample of runoff-sediment mixture was collected from each sampling tank and then the sediment concentration was determined. Sediments deposited along drains and in the sedimentation traps were also collected and dry-weighted. To obtain the sediment yield due to each erosive event, sediment concentration was multiplied by the runoff volume and added to weight of deposited sediments. The soil losses dataset (CANNONA_SOIL_LOSSES.txt) includes the rainfall and runoff variables (the same as the runoff dataset) and the soil losses from the three plots (SL, $\mathrm{kg} \mathrm{ha}^{-1}$ ), which were measured for the erosive events.

A portion of collected runoff samples was used to determine nutrient concentrations in runoff. Ammonium, nitrate, phosphate and potassium were analyzed by lon Cromatography (IC). No data were available for events that occurred in years 2005 and 2010. The nutrient losses were obtained by multiplying the concentration by the runoff.

\subsection{Soil properties}

Since 2004 recurring surveys were carried out to measure soil physical properties in the Cannona Erosion Plots. The measurements were performed once or twice at year, before tillage operations, on three transects in each plot. As the traffic of agricultural machinery was repeated on fixed routes, the measurements of penetration resistance, bulk density and volumetric soil water content were done both in the central part of the inter-row (or no-track, NT) and in the track position (T), that is the portion of soil affected by the passage of tractor wheels or tracks,. Soil penetration resistance was measured by means of a recording penetrometer with a cone angle of $30^{\circ}$ and $1 \mathrm{~cm}^{2}$ area (Walczak et al., 1973) to a depth of $25 \mathrm{~cm}$ with vertical separation distance of $2.5 \mathrm{~cm}$. Bulk density of the soil was determined by the core method (Blake and Hartge, 1986), sampling the soil at depths: 0-7, 10-17, 20$27 \mathrm{~cm}$ using $100 \mathrm{~cm}^{3}$ cores. The same cores were used to determine gravimetric soil water content. Volumetric water content was calculated on the basis of gravimetric water content 
Postprint version of:

Biddoccu et al., 2016. Long-term monitoring of soil management effects on runoff and soil erosion in sloping vineyards in Alto Monferrato (North-West Italy). Soil Till. Res., 155 (2016), pp. 176-189.

https://doi.org/10.1016/j.still.2015.07.005

and bulk density. Data of soil penetration resistance and bulk density are included in the CANNONA_SOIL_PH.txt file.

Several series of infiltration tests were carried out in a 2-years period of observation, using the simplified falling head technique (SFH), proposed by Bagarello et al. (2004), in order to detect the variability of the field-saturated hydraulic conductivity at the surface of the vineyard inter-rows with different conditions depending on soil management. The tests were done in the CT plot, before and after the execution of tillage operations (indicated as undisturbed soil, CT-US, and processed soil, CT-PS, respectively), and in the GC plot at the same time. To assure one-dimensional flow, we used a second ring that was inserted concentric to the inner one. We used PVC cylinders having height of $0.30 \mathrm{~m}$, inner diameter of $0.305 \mathrm{~m}$ (the inner cylinder) and $0.486 \mathrm{~m}$ (the outer one). The applied volumes of water were $7.0 \mathrm{~L}$ in the inner ring and $10.8 \mathrm{~L}$ in the bigger cylinder. Each SFH experiment included from 4 to 8 measurements, which were carried out in the T and in the NT position of the inter-row. The field-saturated hydraulic conductivity can be then determined by knowing: the time $t_{a}$ from the application of water to the instant at which the water is infiltrated in the soil; $\triangle S W C$, which is the difference between the field-saturated and the initial volumetric soil water content, $D=V / A$ (the depth of water corresponding to $V$ ) and $\alpha^{*}$ (a soil texture/structure parameter that can be estimated according to Elrick and Reynolds, 1992a and to Elrick and Reynolds, 1992b). Soil samples were collected to analyze soil physical and chemical properties in 1998, before the beginning of the experiment, in 2004 and 2012. Only texture was analyzed in 2004. Data are included in the CANNONA_TEXTURE.txt and CANNONA_SOIL_CH.txt).

\subsection{Soil water content}

Continuous monitoring of soil water content and soil temperature was performed starting from august 2011 to provide information about space-time variability of hydrological processes, determining the surface runoff response to a given precipitation events. Integrated temperature-soil water content sensors were installed in the topsoil and measures were recorded in one-hour intervals by a data logger. Four 5 TM sensors (Decagon Devices) were installed at $10 \mathrm{~cm}$ depth in each plot, to deliver temperature, measured by an onboard thermistor, along with volumetric soil water content. Measurements were taken on two transects, NT and T positions. Volumetric water content was obtained by measuring the dielectric constant of the soil using capacitance/frequency domain technology and the Topp equation (Topp et al., 1980), resulting in accuracy of \pm 
Postprint version of:

Biddoccu et al., 2016. Long-term monitoring of soil management effects on runoff and soil erosion in sloping vineyards in Alto Monferrato (North-West Italy). Soil Till. Res., 155 (2016), pp. 176-189.

https://doi.org/10.1016/j.still.2015.07.005

$0.03 \mathrm{~m}^{3} / \mathrm{m}^{3}$ ( $\left.\pm 3 \% \mathrm{VWC}\right)$. Accuracy for temperature was $\pm 1^{\circ} \mathrm{C}$. Measurements were recorded every 60 minutes and data are stored by a Decagon EM50 Datalogger.

\subsection{Data availability}

The main objective of the research programs carried out on the Cannona Erosion Plots was the investigation of the effects of soil management on hydrology and soil degradation in vineyards. The aim of the CDB is to make the collected data available for consultation and for use by the public, researchers, students, authorities, farmer organizations and other stakeholders. The CDB website (http://sustag.to.cnr.it/index.php/cannona-db) contains the collected and validated datasets (Table 1) that can be downloaded from the website. The publically available sections of website also include general information and description of the Cannona Erosion Plots, results of the research activities, reports, publications, images, and links to other useful databases. 


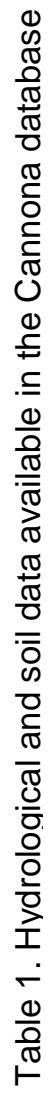

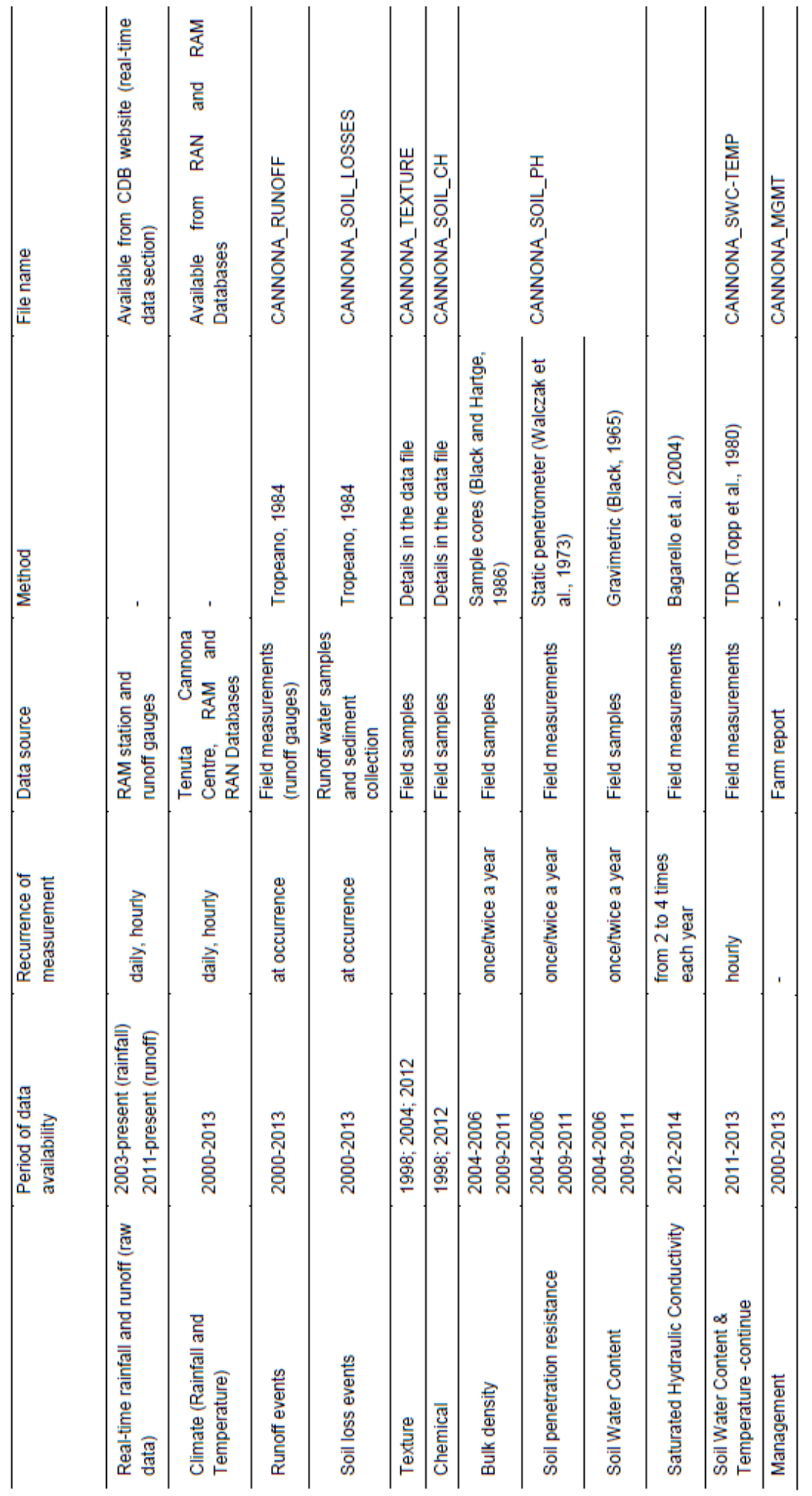


Postprint version of:

Biddoccu et al., 2016. Long-term monitoring of soil management effects on runoff and soil erosion in sloping vineyards in Alto Monferrato (North-West Italy). Soil Till. Res., 155 (2016), pp. 176-189.

https://doi.org/10.1016/j.still.2015.07.005

\section{Results and discussion}

\subsection{Rainfall}

The rainfall observed at the Cannona Experimental Centre are typical for sublitoranean climate (Table 2 and Fig.4). The inter-annual variability of the precipitation was quite high, with the maximum variability observed in autumn (especially in October and November), and the minimum in summer (June). The accumulated annual rainfall ranged from a minimum of $539 \mathrm{~mm}$ (year 2007) to a maximum of $1336 \mathrm{~mm}$ (year 2002), with an average of $849 \mathrm{~mm}$. The rainfall showed a seasonal pattern: autumn was the wettest period (average $40 \%$ of the annual precipitation), whereas summer was usually the driest ( $12 \%$ on average).

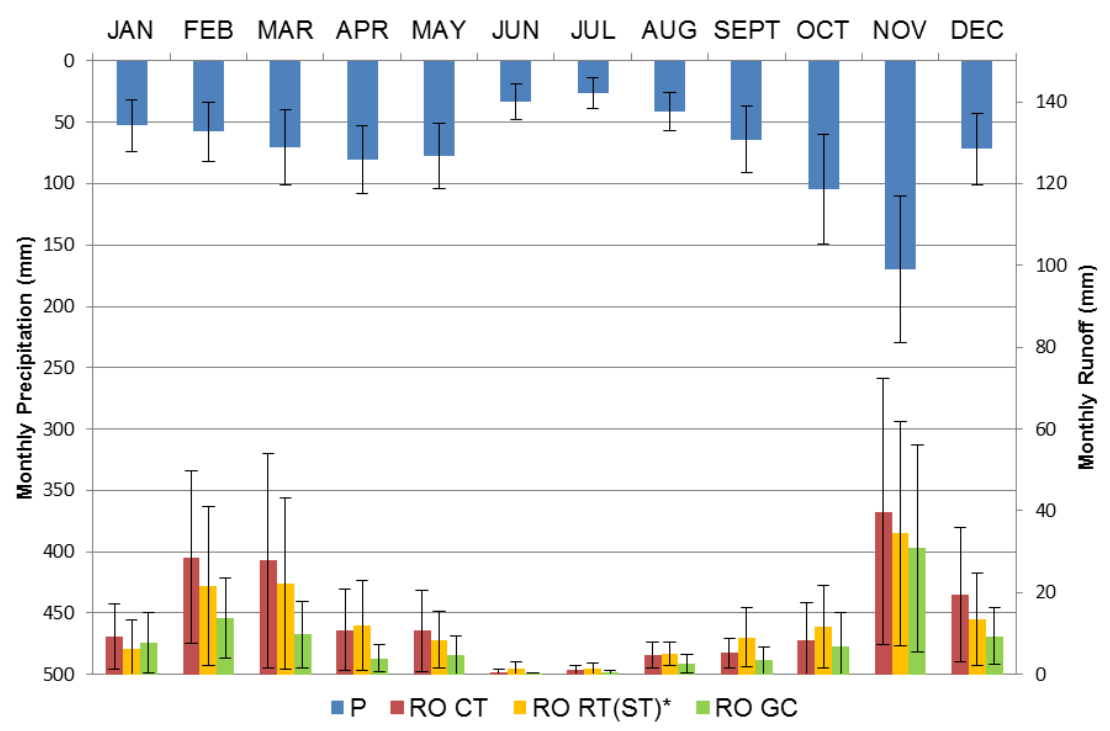

Fig.4. Measured monthly precipitation $(P)$ and annual cumulative runoff $(R O)$ from the Cannona Erosion Plots $(C T=$ conventional tillage; $\mathrm{RT}(\mathrm{ST})=$ reduced tillage, converted in conventional tillage with grass strip (ST); $\mathrm{GC}=$ grass cover).

Table 2. Mean seasonal values (and standard deviation, SD) of precipitation (P), runoff $(R O)$ and runoff coefficients $(R C)$ measured at the Cannona Erosion Plots (CT = conventional tillage; $R T(S T)=$ reduced tillage converted in conventional tillage with grass strip; GC = grass cover) during the period 2000-2013.

\begin{tabular}{|c|c|c|c|c|c|c|}
\hline & & $\begin{array}{l}\text { Sept-Oct- } \\
\text { Nov }\end{array}$ & $\begin{array}{c}\text { Dec-Jan- } \\
\text { Feb }\end{array}$ & $\begin{array}{c}\text { Mar-Apr- } \\
\text { May }\end{array}$ & $\begin{array}{l}\text { Jul-Jun- } \\
\text { Aug }\end{array}$ & Total \\
\hline \multirow{2}{*}{$P(\mathrm{~mm})$} & Mean & 338.4 & 181.7 & 228.3 & 100.5 & 848.9 \\
\hline & SD & -150.4 & -97.5 & -102.5 & -52.6 & -234.3 \\
\hline \multirow{3}{*}{$\begin{array}{c}R O C T \\
(\mathrm{~mm})\end{array}$} & Mean & 53.3 & 57.4 & 49.4 & 6.3 & 166.3 \\
\hline & SD & -70.3 & -56.1 & -65.5 & -7.1 & -121.2 \\
\hline & Mean & 55.2 & 41.4 & 42.5 & 8 & 147.1 \\
\hline
\end{tabular}


Postprint version of:

Biddoccu et al., 2016. Long-term monitoring of soil management effects on runoff and soil erosion in sloping vineyards in Alto Monferrato (North-West Italy). Soil Till. Res., 155 (2016), pp. 176-189.

https://doi.org/10.1016/j.still.2015.07.005

\begin{tabular}{ccccccc}
\hline $\begin{array}{c}\text { RO RT } \\
(\mathrm{ST})(\mathrm{mm})\end{array}$ & $\mathrm{SD}$ & -59.2 & -43.3 & -54.2 & -7.3 & -94.9 \\
$\begin{array}{c}R O \mathrm{GC} \\
(\mathrm{mm})\end{array}$ & Mean & 41.1 & 30.7 & 18.3 & 3.1 & 93.3 \\
& $\mathrm{SD}$ & -59.4 & -23.7 & -19.6 & -4.9 & -67.8 \\
$R C \mathrm{CT}(\%)$ & Mean & 11.8 & 27.8 & 17.5 & 5.8 & 17.9 \\
& $\mathrm{SD}$ & -11.4 & -23.7 & -23 & -6.1 & -10.9 \\
$R C \mathrm{RT}(\mathrm{ST})$ & Mean & 13.4 & 19.7 & 15 & 7.6 & 16.1 \\
$(\%)$ & $\mathrm{SD}$ & -9.2 & -18.1 & -17.7 & -6.5 & -8.3 \\
& Mean & 8.7 & 15.2 & 6.4 & 2.8 & 10 \\
$R C \mathrm{GC}(\%)$ & $\mathrm{SD}$ & -9.3 & -9.4 & -6.5 & -3.9 & -5 \\
\hline
\end{tabular}

Rainfall data at the Ovada weather station were used to obtain the $\mathrm{El}_{30}$ rainfall erosivity index (Morgan, 2005) and rainfall events were classified following the cumulated rainfall depth (Table 3). More than $80 \%$ of the rainfall occurred during events cumulating less than $100 \mathrm{~mm}$. The mean erosivity of each of those classes was lower than $200 \mathrm{MJ} \mathrm{mm} \mathrm{ha}^{-1} \mathrm{~h}^{-1}$ and the corresponding cumulated erosivity accounted for the $59 \%$ of the total. Rainfall events with more than $100 \mathrm{~mm}$ of precipitation showed higher mean rainfall erosivity, up to more than 2,000 MJ mm ha-1 $\mathrm{h}^{-1}$. Less than 20 events accounted for more than $40 \%$ of the total erosivity. Just few events had very high erosivity (>1000 MJ mm ha-1 $\left.\mathrm{h}^{-1}\right)$ and they occurred mainly during autumn.

Table 3. Rainfall characteristics for categorized precipitation events in the period 2000-2013, measured at the Ovada weather station. El 30 was calculated in according to Brown and Foster (1987).

\begin{tabular}{lcccccc}
\hline $\begin{array}{c}\text { Rainfall events } \\
\text { category } \\
(\mathrm{mm})\end{array}$ & $\begin{array}{c}\text { Number of } \\
\text { events }\end{array}$ & $\begin{array}{c}\text { Av. rainfall } \\
\text { depth } \\
(\mathrm{mm})\end{array}$ & $\begin{array}{c}\text { Av. storm } \\
\text { duration } \\
(\mathrm{h})\end{array}$ & $\begin{array}{c}\text { Av. Rainfall } \\
\text { Erosivity El } \\
\mathrm{MJ} \mathrm{mm} \mathrm{ha}^{-1} \mathrm{~h}^{-1}\end{array}$ & $\begin{array}{c}\text { Cumulated } \\
\text { rainfall } \\
(\%)\end{array}$ & $\begin{array}{c}\text { Cumulated Rainfall } \\
\text { Erosivity EI }_{30} \\
(\%)\end{array}$ \\
\hline $0-10$ & 810 & 2.4 & 3.7 & 1.4 & 15 & 4 \\
$10-20$ & 131 & 14.1 & 12.7 & 20.9 & 29 & 15 \\
$20-30$ & 68 & 24.7 & 16.6 & 51.7 & 42 & 28 \\
$30-40$ & 22 & 34.2 & 26.8 & 34.8 & 47 & 31 \\
$40-50$ & 26 & 45.6 & 29.2 & 58.0 & 56 & 37 \\
$50-60$ & 13 & 54.6 & 26.5 & 82.0 & 62 & 41 \\
$60-70$ & 12 & 64.8 & 37.8 & 115.4 & 68 & 47 \\
$70-80$ & 8 & 74.1 & 42.7 & 196.8 & 72 & 53 \\
$80-90$ & 9 & 84.4 & 40.8 & 138.1 & 78 & 57 \\
$90-100$ & 4 & 91.7 & 66.1 & 91.3 & 81 & 59 \\
$100-150$ & 10 & 118.3 & 51.6 & 255.7 & 90 & 68 \\
$150-200$ & 4 & 184.9 & 50.0 & 964.1 & 96 & 83 \\
$>200$ & 2 & 292.5 & 65.7 & $2,185.5$ & 100 & 100 \\
\hline
\end{tabular}


Postprint version of:

Biddoccu et al., 2016. Long-term monitoring of soil management effects on runoff and soil erosion in sloping vineyards in Alto Monferrato (North-West Italy). Soil Till. Res., 155 (2016), pp. 176-189.

https://doi.org/10.1016/j.still.2015.07.005

\subsection{Runoff}

\subsubsection{Seasonal distribution}

The inter-annual variability of the runoff volumes measured at the Cannona Erosion Plots was very high, especially in autumn when the maximum variability was observed for the three treatments, meanwhile the minimum variability was in summer (Table 2 and Fig.4). Average runoff discharges during the year followed a pattern similar to precipitation. In all treatments, runoff showed high values in autumn and winter. The highest runoff amounts were measured in November, in response to mean rainfall depth greater than $150 \mathrm{~mm}$. High mean runoff values in February and March were likely due to snowmelting. The highest mean runoff rates were obtained in winter: in this season snowfalls occurred nearly every year, sometimes followed by rainfall, and soil moisture conditions were thus close to saturation for long periods, fostering runoff formation. During spring, mean runoff was about $30 \%$ of the annual volume for the tilled plots, with runoff rates higher than in autumn, partly due to early-spring snowfalls. From April through early autumn, new grass has usually grown spontaneously in the inter-rows of the three plots, resulting in different grass cover depending on the adopted soil management treatment. After the execution of tillage and grass mulching, the vegetation was mechanically eliminated and incorporated into the soil (in $\mathrm{CT}$ and $\mathrm{RT}(\mathrm{ST})$ ) and, in GC, grass was cut with mulcher and residues were left on the soil surface. Thus, in spring and autumn, the inter-row surface of the three plots was partially covered by grass, which affect differently the hydrological processes. Spring runoff was reduced to $20 \%$ of the annual amount with the GC treatment, resulting in mean runoff rate lower than in autumn, because of the effect of the new grass cover. Nevertheless, during spring and autumn mean rainfall were more abundant, runoff rates were lower than in winter for all treatments. Beyond the before-mentioned reasons, this was likely due to the high infiltration rates that soil exihibits closer to the tillage operations (Ruiz-Colmenero et al., 2011; Biddoccu et al., 2013) which were usually made in spring and autumn. Less than $5 \%$ of the annual runoff was measured in summer time from the three plots. This was due to the low rainfall depth and high evapotraspiration, but also to the effect of the late-spring tillage, in 
Postprint version of:

Biddoccu et al., 2016. Long-term monitoring of soil management effects on runoff and soil erosion in sloping vineyards in Alto Monferrato (North-West Italy). Soil Till. Res., 155 (2016), pp. 176-189.

https://doi.org/10.1016/j.still.2015.07.005
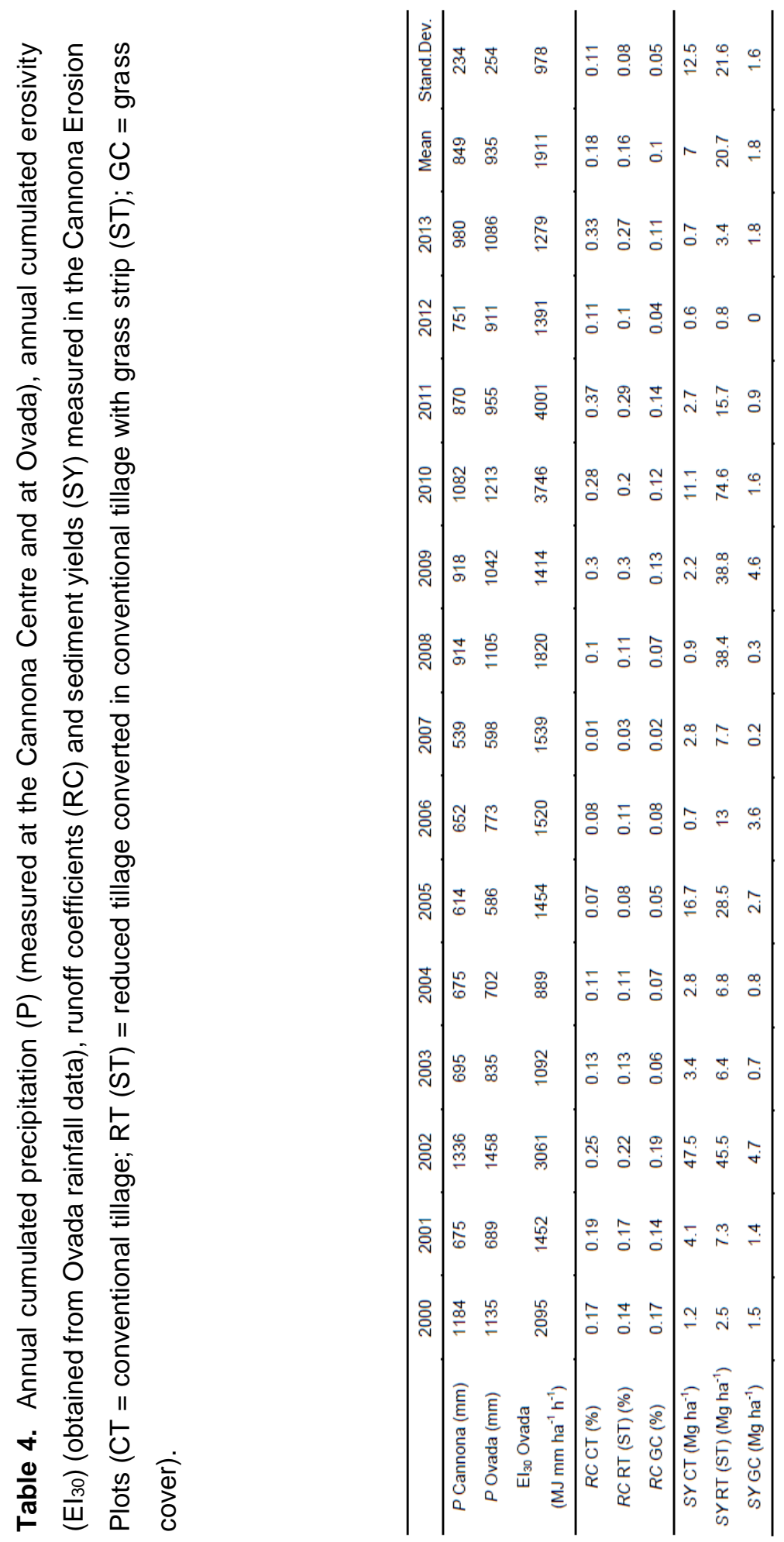
Postprint version of:

Biddoccu et al., 2016. Long-term monitoring of soil management effects on runoff and soil erosion in sloping vineyards in Alto Monferrato (North-West Italy). Soil Till. Res., 155 (2016), pp. 176-189.

https://doi.org/10.1016/j.still.2015.07.005

$\mathrm{CT}$ and RT(ST) treatments, and to the presence of grass cover in the GC plot and also in other treatments, in late summer.

The highest runoff mean volumes were measured in the RT plot from April to October, with exclusion of May, when the soil was usually tilled. From November to March (and in May) the highest mean runoff was observed in the CT plot. The GC treatment showed the lowest runoff during the whole year (excepted January). During spring and summer the use of grass cover resulted in a mean runoff reduction higher than $50 \%$ with respect to the tilled treatments, but it was less effective in autumn and winter, when the grass is sparsely developed. In summer and early autumn many farming operations, including harvest, are usually carried out in the vineyard using tractors, with traffic going in the direction of the maximum slope. This causes a reduction of grass cover and increasing compaction level just before the most rainy season, and tractor tracks become path of preferential flows in runoff generation.

\subsubsection{Annual distribution}

Accumulated annual runoff (Table 4) ranged between 6.6 and $339.1 \mathrm{~mm}$ for CT, 15.2 and $293.9 \mathrm{~mm}$ for RT, 10.9 and $247.3 \mathrm{~mm}$ for GC, measured respectively in 2007 and 2002, which were above mentioned as the dryer and wetter years, respectively. With the exclusion of the driest year, during which the runoff rates were lower than $3 \%$ for all treatments, the yearly runoff rates ranged between $7 \%$ and $37 \%$ for CT, $8 \%$ and $30 \%$ for RT(ST), and $5 \%$ and $19 \%$ for GC (Fig. 5). For most of the years, runoff measured in each treatment was higher than $7.4 \%$, which is the mean value obtained from values by 123 plot-year measurements carried out 
Postprint version of:

Biddoccu et al., 2016. Long-term monitoring of soil management effects on runoff and soil erosion in sloping vineyards in Alto Monferrato (North-West Italy). Soil Till. Res., 155 (2016), pp. 176-189.

https://doi.org/10.1016/j.still.2015.07.005
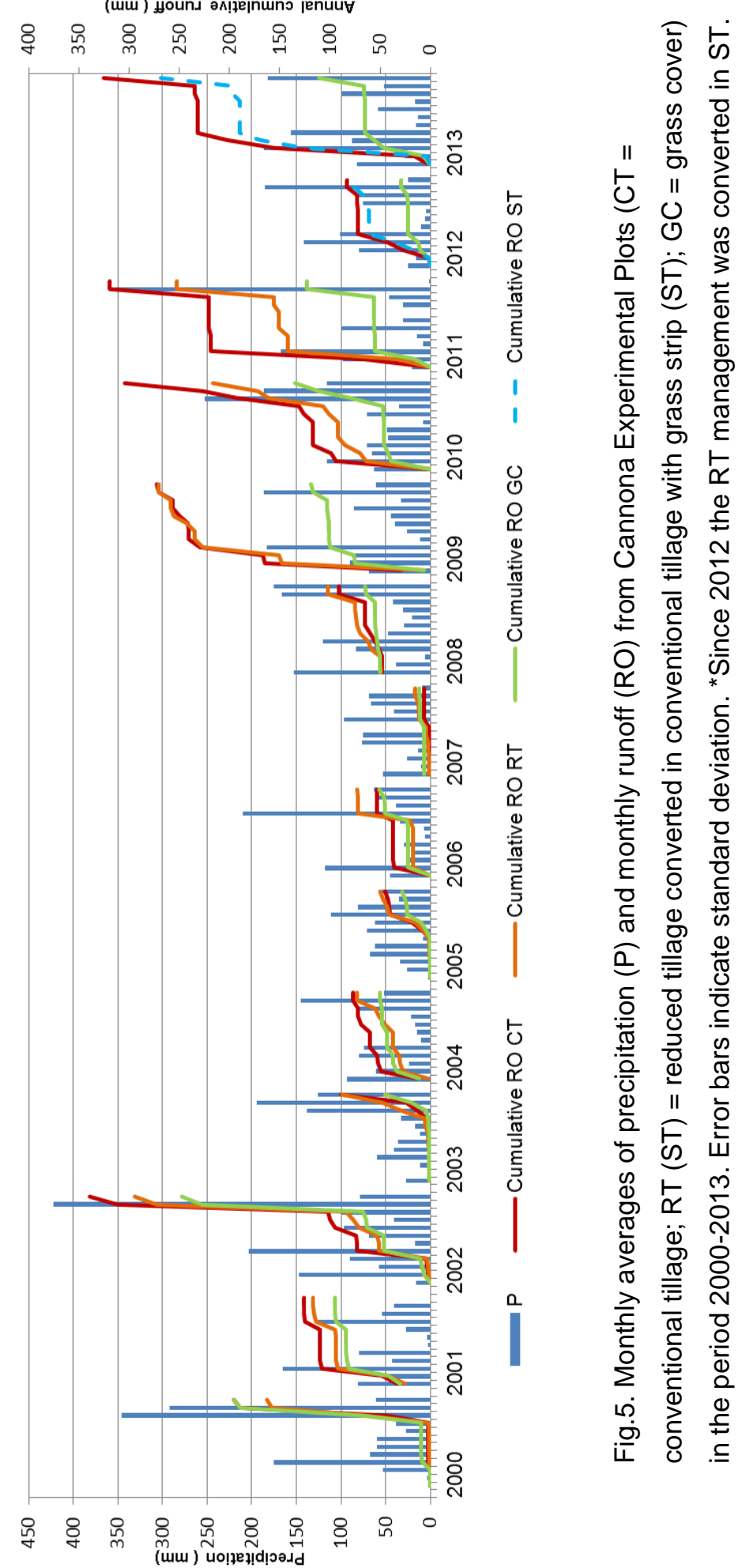

in vineyards managed with different techniques in the European region (Maetens et al., 2012). The results of the current study were consistent with runoff rates obtained over 12 years in ploughed vineyards (with vine rows perpendicular to maximum slope direction), which ranged from 7.5\% to 40.7\%. (Ramos \& Martínez-Casasnovas, 2010). The nonparametric test Mann-Whitney showed the significativity of the difference between runoff 
Postprint version of:

Biddoccu et al., 2016. Long-term monitoring of soil management effects on runoff and soil erosion in sloping vineyards in Alto Monferrato (North-West Italy). Soil Till. Res., 155 (2016), pp. 176-189.

https://doi.org/10.1016/j.still.2015.07.005

rates measured in CT and RT(ST) treatments during years 2000-2008 and years 2009-2013 for the spring months (March and April, at least at the 0.1 probability level) and for the whole year (at 0.05 probability level for CT and 0.1 for RT(ST)), but not in October and November, which are the most rainy months. No significant differences were found between the two periods for the GC runoff rates. Increase in the runoff rates measured in the CT and RT(ST) plot is likely an effect of the adoption of tillage for 9 consecutive years, which caused soil degradation and higher runoff in following years, especially during spring months, which was not so evident in the GC treatment.

\subsection{Bulk density, soil penetration resistance and saturated hydraulic conductivity}

Soil bulk density and penetration resistance were measured in the three plots over the period 2004-2011, before tillage in spring and autumn. Soil penetration resistance was significantly higher in the GC treatment than in the tilled plots, because of the presence of grass roots. In the CT and RT plots soil penetration resistance was significantly higher in the $\mathrm{T}$ position and in autumn rather than in spring (Fig.6). Bulk density results in Table 5 showed that the tilled plots were subjected to a greater extent to soil compaction
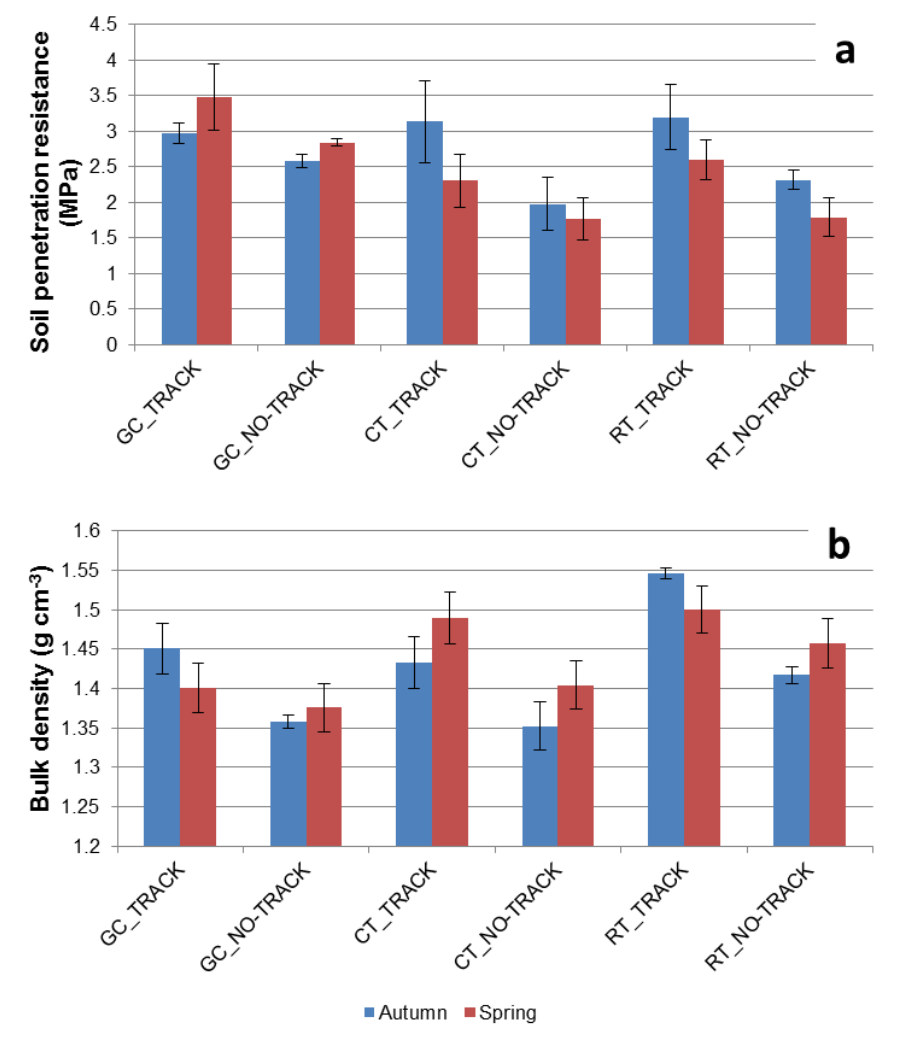

Fig.6. Mean values of soil penetration resistance (a) and bulk density (b), obtained from yearly measurements varied out in autumn and spring (before tillage operations), from 2004 to 2011 . Error bars indicate standard deviation. 
Postprint version of:

Biddoccu et al., 2016. Long-term monitoring of soil management effects on runoff and soil erosion in sloping vineyards in Alto Monferrato (North-West Italy). Soil Till. Res., 155 (2016), pp. 176-189.

https://doi.org/10.1016/j.still.2015.07.005

induced by tractor traffic, particularly in the T position, where mean values were significantly higher than in the NT position. Saturated hydraulic conductivity (Table 5) was also significantly lower in the T position than in NT, both in the GC treatment than in the CT-US condition. Significantly higher hydraulic conductivity was measured in the CT-PS condition, within a month after tillage operation, without differences in T and NT positions. Low water infiltration in the CT and RT(ST) plots is likely caused by high soil compaction, especially long time after the tillage operations, fostering the runoff formation.

Table 5. Mean and coefficient of variation (CV, in \%) of the soil parameters measured in the experimental plots in the No Track and Track position. Soil penetration resistance and bulk density were measured in the period 2004-2011 in the three plots (GC = grass cover; CT = conventional tillage; RT = reduced tillage). Fieldsaturated hydraulic conductivity was measured with the SFH technique in three soil conditions: $\mathrm{GC}$ = grass cover, CT-US = conventional tillage with undisturbed soil, CT-PS = conventional tillage after soil tillage. Mean values in bold showed a significant difference between the two positions, according to the t-test at the 0.05 probability level; means followed by different letters differ at the same test and probability level.

\begin{tabular}{|c|c|c|c|c|c|c|c|c|c|c|}
\hline & & \multicolumn{3}{|c|}{$\overline{G C}$} & \multicolumn{3}{|c|}{ CT } & \multicolumn{3}{|c|}{ RT } \\
\hline & & NT & $T$ & Tot & NT & $\mathrm{T}$ & Tot & NT & $\mathrm{T}$ & Tot \\
\hline $\begin{array}{l}\text { Soil Penetration } \\
\text { Resistance }\end{array}$ & Mean & 2.74 & 3.28 & $3.01 \mathrm{a}$ & 1.85 & 2.64 & $2.25 b$ & 2.03 & 2.87 & $2.45 \mathrm{~b}$ \\
\hline \multirow[t]{2}{*}{ (MPa) } & $\mathrm{CV}$ & 7.0 & 23.3 & 20.3 & 33.6 & 36.8 & 39.7 & 24.9 & 26.7 & 31.2 \\
\hline & Mean & 1.36 & 1.41 & $1.39 a$ & 1.37 & 1.47 & $1.42 \mathrm{ab}$ & 1.43 & 1.51 & $1.47 \mathrm{~b}$ \\
\hline \multirow{3}{*}{$\begin{array}{l}\text { Bulk Density } \\
\qquad\left(\mathrm{g} \mathrm{cm}^{-3}\right)\end{array}$} & $\mathrm{CV}$ & 3.6 & 4.8 & 4.5 & 6.4 & 4.4 & 6.4 & 4.7 & 3.3 & 4.9 \\
\hline & & \multicolumn{3}{|c|}{ GC } & \multicolumn{3}{|c|}{ CT-US } & \multicolumn{3}{|c|}{ CT-PS } \\
\hline & & NT & $\mathrm{T}$ & Tot & NT & $\mathrm{T}$ & Tot & NT & $\mathrm{T}$ & Tot \\
\hline $\begin{array}{c}\text { Saturated } \\
\text { Hydraulic } \\
\text { Conductivity }\end{array}$ & Mean & \begin{tabular}{|l|}
327.8 \\
\end{tabular} & 139.3 & $204.3 a$ & 362.2 & 29.5 & $107.6 \mathrm{a}$ & 1501.9 & 549.6 & $951.0 \mathrm{~b}$ \\
\hline$\left(\mathrm{mm} \mathrm{h}^{-1}\right)$ & CV & 48.3 & 58.2 & 57.3 & 58.7 & 35.2 & 81.4 & 43.4 & 159.9 & 211.3 \\
\hline
\end{tabular}

\subsection{Soil water content}

The daily average values of soil water content (SWC), measured in different positions in the topsoil of the three plots are shown in Figure 7 (a,b,c). The measured SWC ranged between 0.15 and $0.59 \mathrm{~m}^{3} / \mathrm{m}^{3}$, with highest values obtained in winter 2013 in the CT plot, in the track 
Postprint version of:

Biddoccu et al., 2016. Long-term monitoring of soil management effects on runoff and soil erosion in sloping vineyards in Alto Monferrato (North-West Italy). Soil Till. Res., 155 (2016), pp. 176-189.

https://doi.org/10.1016/j.still.2015.07.005

position. In the wet seasons (autumn, winter, and spring), runoff seemed to be mainly generated by saturation of the uppermost soil layers, according to Castillo et al. (2003).

In the CT treatment, SWC in the track (T) position was usually higher than in central or notrack (NT) position, with exclusion of the first month after tillage in 2012 (spring and autumn). SWC
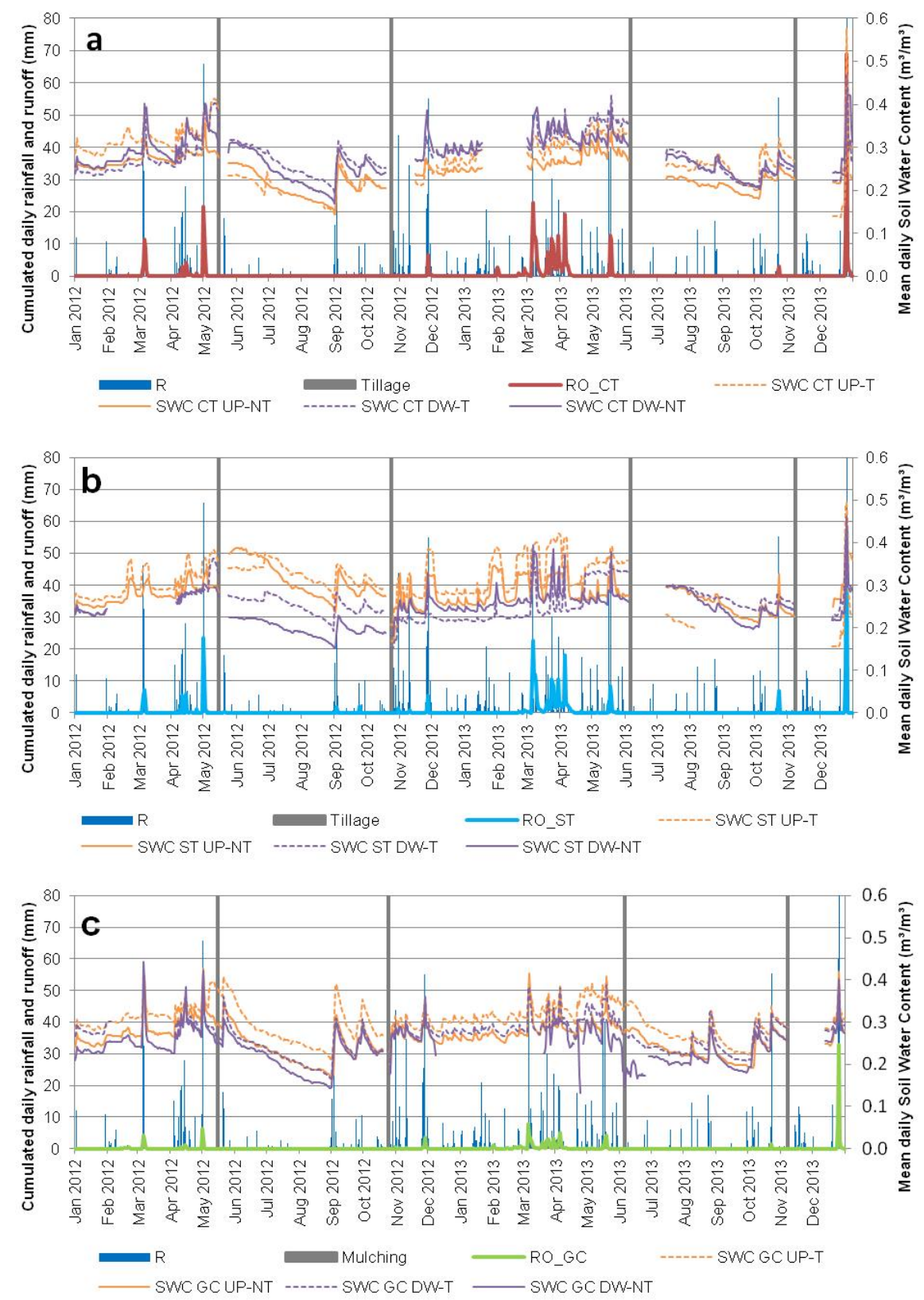

Fig.7. Soil water content $(\mathrm{SWC})$ measured at $10 \mathrm{~cm}$ depth in two transects (UP = upwards, DW = downwards) and two positions of the inter-rows ( $T=$ track, NT = no-track) in each of the Cannona Erosion Plots: (a) conventional tillage (CT) (b) conventional tillage with grassed strip (ST) (c) grass cover (GC) in the period 2012-2013. 
Postprint version of:

Biddoccu et al., 2016. Long-term monitoring of soil management effects on runoff and soil erosion in sloping vineyards in Alto Monferrato (North-West Italy). Soil Till. Res., 155 (2016), pp. 176-189.

https://doi.org/10.1016/j.still.2015.07.005

values measured in the two positions were very similar in the lower portion of the plot. During the first months of 2012 and in autumn 2013, SWC was higher in the upper portion than in the lower part of the vineyard, otherwise the bottom was usually the wettest portion of the inter-rows. In the ST plot, SWC was usually higher in the T position than in the NT position in the upper transect, except for first period after tillage in spring 2012. In the lower portion of the plot, the SWC was also higher in the T position than in NT for most of the time, with exception of the period from 11/2012 to 5/2013. The SWC was usually higher in the upper part of the plot than in the lower portion, with the exception of the driest summer months in 2013. Hajabbasi and Hemmat (2000) observed in clay-loam soil a change in soil properties, following the use of rotary cultivator for some years. The history of cultivation and the structure of the first centimeters of the soil were found also to be major causes in variability of infiltration rates in vineyards (Leonard and Andrieux, 1999). Thus, we can suppose that the history of the soil management could be the major cause of differences in spatial distribution of SWC between CT and ST. Nevertheless, both in the CT and in the ST plot, in which soil is managed with tillage, the SWC was usually higher in the T position than in NT, with exclusion of a period (up to two months) after the tillage operation. In the GC plot, the SWC measured in the T position was higher than in the NT position along the two years. SWC was slightly higher in the upper portion of the slope during most of year 2012 and during summer months of 2013. From 11/2012 to 6/2013, SWC was very similar in the upper and lower portion of the GC plot. As already observed by Ferrero et al. (2005) and Opsi et al. (2012) the tractor traffic in vineyards has a great influence on the spatial variability of soil physical properties, which are strictly related to the topsoil water content. The recurrence of tillage could temporarily decrease this effect, but it affects the variability of soil properties over a long period.

\subsection{Soil erosion}

\subsubsection{Seasonal distribution}

Main sediment yield occurred in August for CT, in October for RT(ST) and in November for GC, in response to increasing erosivity of rainfall from August to November (Fig.8). High average values that were measured for soil losses in autumn were likely due to high mean erosivity (>400 MJ mm ha-1 $\mathrm{h}^{-1}$ ) and, in November, also to the highest runoff amounts. On the contrary, in July and August rainfall events were characterized by mean erosivity lower than $200 \mathrm{MJ} \mathrm{mm} \mathrm{ha-1} \mathrm{h}^{-1}$ and generated low runoff mean values. The erosive events were 
Postprint version of:

Biddoccu et al., 2016. Long-term monitoring of soil management effects on runoff and soil erosion in sloping vineyards in Alto Monferrato (North-West Italy). Soil Till. Res., 155 (2016), pp. 176-189.

https://doi.org/10.1016/j.still.2015.07.005

concentrated in summer and autumn. In summer, the late spring/summer tillage and the absence (or scarcity) of soil cover were the most likely reasons for high soil losses in the tilled plots. A previous study by Biddoccu et al. (2013) showed that the effect of spring and autumn tillage in reducing runoff was limited only to one or two rainfall events, but during the following events higher runoff rates were recorded. Moreover, rotary cultivator tends to break up soil clods into smaller sizes, which are more susceptible to breakdown with respect to soil treated with chisel cultivation. Consequently, few rainfall events that occurred during summer were able to generate high sediment yield, especially where soil was processed with RT, even if the mean runoff was not so high. In autumn the occurrence of highly erosive events was due to the combination of severe soil compaction (in October, before tillage) or high soil water content (in November, after tillage), and low cover. As discussed before, those factors were responsible for large runoff, especially in November, and thus high energy rainfall resulted in high erosion of the poorly protected soil. The grass cover was especially effective in reducing soil losses in GC during summer months, but its protective effect decreased in autumn, as was also observed in a olive farm by Gomez et al. (2014). Farming operations that are usually carried out in summer and especially in autumn on wet soil results in soil compaction and low cover, and finally the autumn mowing expose soil to increasing soil erosion. During winter and spring months, mean soil losses were negligible ( $<1 \mathrm{Mg} \mathrm{ha}^{-1}$ ) for CT and GC, and slightly higher for the RT treatment.

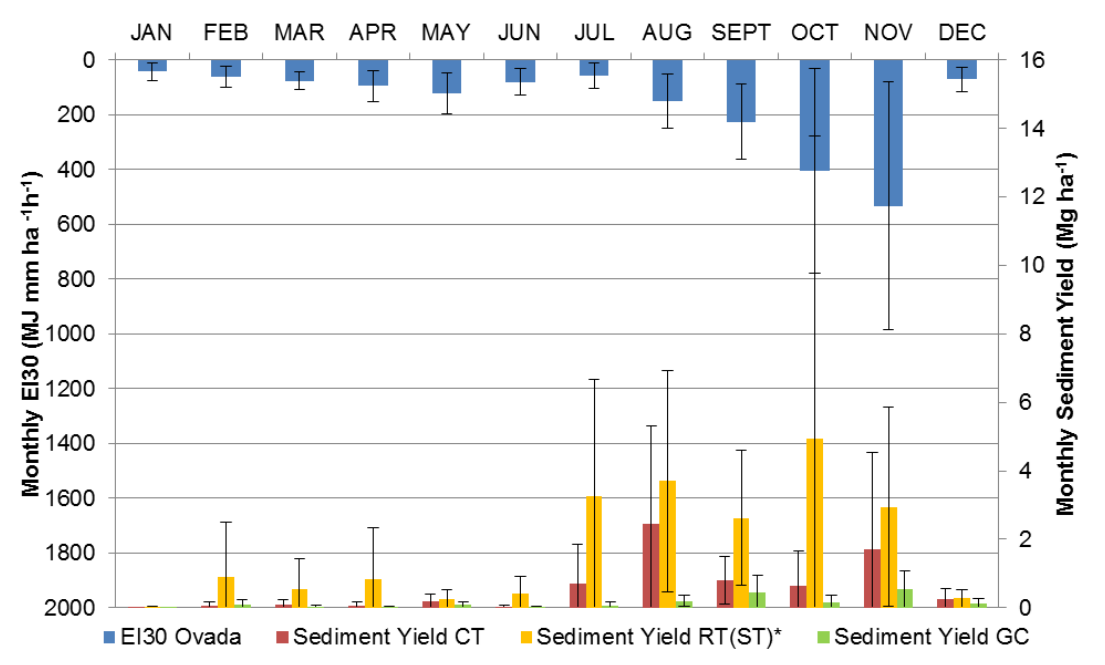

Fig.8. Monthly averages of rainfall erosivity $\left(\mathrm{El}_{30}\right)$ at Ovada station and monthly sediment yield measured from the experimental plots in the period 2000-2013. Error bars indicate standard deviation. * Since 2012 the RT management was converted in ST. 
Postprint version of:

Biddoccu et al., 2016. Long-term monitoring of soil management effects on runoff and soil erosion in sloping vineyards in Alto Monferrato (North-West Italy). Soil Till. Res., 155 (2016), pp. 176-189.

https://doi.org/10.1016/j.still.2015.07.005

\subsubsection{Annual distribution}

Figure 8 displays the monthly averages of rainfall erosivity (EI30), obtained from rainfall data recorded at the Ovada station, and averages of monthly sediment yield measured from the experimental plots in the period 2000-2013. Sediment yield presented very high inter-annual variability, with the highest values for $\mathrm{RT}(\mathrm{ST})$ treatment, especially for months from July to November. Annual sediment yield ranged from 0.06 to $47.5,0.8$ to 74.6 , and 0.0 to $4.7 \mathrm{Mg}$ ha $^{-1}$ year $^{-1}$, respectively for the CT, RT(ST), and GC treatments.

Annual sediment yield was similar for the three plots in 2000 (Fig.9), then it was usually highest in RT plot (excepted 2002) and lowest for GC treatment (with exclusion of years 2006 and 2009), which resulted in a mean sediment yield of about $1.8 \mathrm{Mg} \mathrm{ha}^{-1}$ year-1 (Table 5). The mean sediment yield in RT was $20.7 \mathrm{Mg} \mathrm{ha}^{-1}$ year $^{-1}$, nearly three times greater than mean soil losses measured in the CT plot. In 2008, 2009 and 2010 the sediment yield was up to 43 times higher for RT than in CT treatment. Rainfall intensity, rainfall erosivity, and soil condition at event occurrence were responsible for such high soil erosion. We can observe that one of the most erosive event (about $2500 \mathrm{MJ} \mathrm{mm} \mathrm{ha}^{-1} \mathrm{~h}^{-1}$ ) occurred in October, 2010 , resulting in the highest monthly soil losses ever recorded for the RT plot $65.88 \mathrm{Mg}$ ha $^{-1}$ ). The highest erosive event event occurred in November, 2011, 20 days after the execution of tillage operations, and resulted in soil losses lower than 1.5 and $4 \mathrm{Mg} \mathrm{ha}^{-1}$ year${ }^{1}$, for $\mathrm{CT}$ and RT, respectively. In this case, the high hydraulic conductivity due to the tillage effect was responsible for relatively low soil erosion. The considerable 
Postprint version of:

Biddoccu et al., 2016. Long-term monitoring of soil management effects on runoff and soil erosion in sloping vineyards in Alto Monferrato (North-West Italy). Soil Till. Res., 155 (2016), pp. 176-189.

https://doi.org/10.1016/j.still.2015.07.005

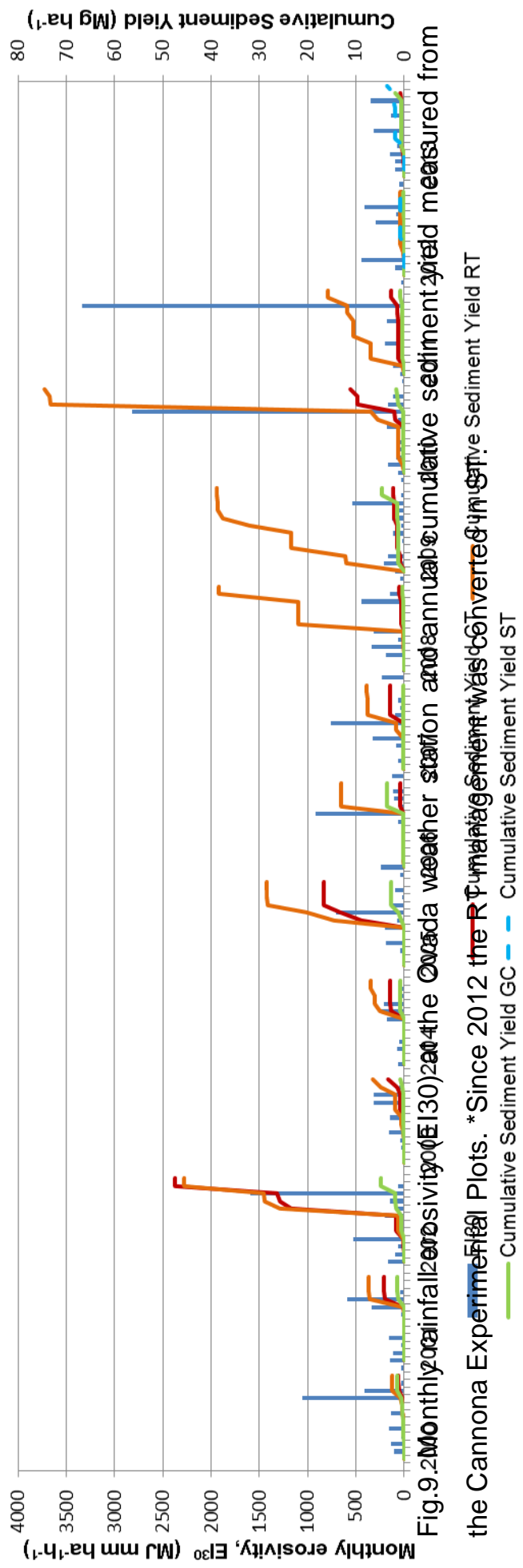


Postprint version of:

Biddoccu et al., 2016. Long-term monitoring of soil management effects on runoff and soil erosion in sloping vineyards in Alto Monferrato (North-West Italy). Soil Till. Res., 155 (2016), pp. 176-189.

https://doi.org/10.1016/j.still.2015.07.005

increase in soil losses that the RT treatment showed from 2008 onwards is likely due to the degradation of soil properties as a consequence of the recurring tillage with rotary cultivator, for more than 8 consecutive years. Similarly, in a clay-loam soil, Hajabbasi and Hemmat (2000) observed that the use of rotary cultivator resulted, in some years, in a decrease of aggregate stability and organic content in the topsoil. Furthermore Barthès and Roose (2002) reported that runoff rate and soil losses were negatively correlated with topsoil aggregate stability, especially on vineyard hillsides.

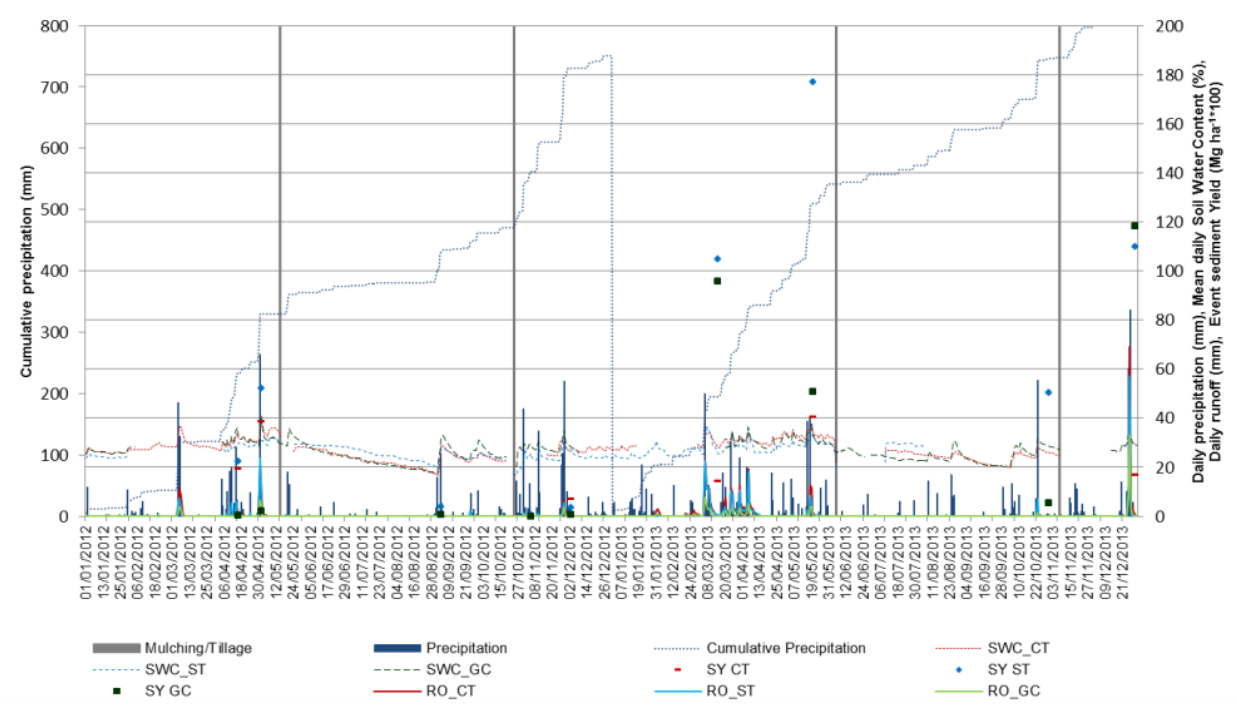

Fig.10. Daily and annual cumulative precipitation measured at the Cannona meteorological station; daily mean soil water content at $10 \mathrm{~cm}$ depth (SWC), daily runoff (RO), event sediment yield (SY) measured in each Erosion Plot $(\mathrm{CT}=$ conventional tillage; $\mathrm{ST}=$ conventional tillage with grass strip; $\mathrm{GC}=$ grass cover $)$ in the years 2012 and 2013.

Figure 10 shows the measured rainfall events, mean daily topsoil water content, daily runoff and event sediment yield during the years 2012 and 2013. No erosive events occurred in summer months, as they were very dry. The main erosive events were concentrated from late fall to late spring, when the soil presented high soil water content, and usually long time after the execution of tillage (in CT and RT(ST)) and mulching (in GC) operations. The response of topsoil in increasing soil water content was evident for daily rainfall higher than $20 \mathrm{~mm}$. Largest runoff and erosive events occurred when large or intense rainfall fell on a moist soil. Sediment yield was much higher in CT and ST than in GC in spring 2012, and it was the lowest in CT for all events occurred in 2013. For all erosive events, the highest sediment yield was measured in the ST treatment. The GC plot also produced high soil losses during the rainfall events occurred on March and December 2013, both occurred when grass cover was poorly developed. Despite the soil management being the same in 
Postprint version of:

Biddoccu et al., 2016. Long-term monitoring of soil management effects on runoff and soil erosion in sloping vineyards in Alto Monferrato (North-West Italy). Soil Till. Res., 155 (2016), pp. 176-189.

https://doi.org/10.1016/j.still.2015.07.005

the CT and ST plot since 2012, except for the presence of the grass strip at the bottom of the ST plot, noticeable differences in sediment yield were observed. They could be ascribed to the history of the soil management, that resulted in degradation of soil properties and, thus, high runoff and soil erosion. In the first two years of installation, the grass strip had no effect in reducing the runoff and soil erosion. Nevertheless, the results suggest that it is difficult to evaluate all the effects of the strip in the ST plot compared to the CT, since the different management of the two plots in the previous period had a great influence in determining the response of the soil to rainfall events, as was also observed in terms of soil water content.

\subsection{Nutrient losses}

The seasonal and total losses of nutrients obtained from the analysis of water samples collected after 80 runoff events are presented in Table 6 . The total yield of ammoniacal nitrogen $\left(\mathrm{NH}_{4}-\mathrm{N}\right)$ was highest from the CT plot, with a $38 \%$ and $61 \%$ reduction, the $\mathrm{RT}$ and GC plots, respectively. The seasonal losses were the highest in CT during all seasons, with the exception of autumn, when the amount of ammoniacal nitrogen lost in RT was slightly higher than in $\mathrm{CT}$. The nitrate $\left(\mathrm{NO}_{3}-\mathrm{N}\right)$ losses were also maxima in the CT plot and reduced by $34 \%$ and $78 \%$ in the RT and GC plots, respectively. Only during summer events the nitrates losses were higher in the RT plot than in other treatments. More than $50 \%$ of the nitrate losses were measured during runoff events that occurred in autumn in all plots, whereas during summer, losses were negligible in CT and GC treatments. With some exceptions, the seasonal yields of nitrates reflect the runoff distribution, as was expected because of nitrate solubility. Despite runoff from the GC plot being the highest, losses of ammoniacal nitrogen, and especially of nitrate, were considerably reduced with the adoption of grass cover.

The total phosphate $\left(\mathrm{PO}_{4}^{3-}\right)$ yields was highest in the $\mathrm{GC}$ plot, and was reduced by at least $20 \%$ in the tilled plots. According to these results, the presence of grass cover had no effect in reducing the total quantity of phosphate losses in the vineyard, especially during winter events. Phosphate losses were highest in GC during winter and summer events, whereas in autumn and spring the RT plot showed the highest losses. Most of phosphate losses occurred during winter events in CT and GC and in autumn in RT. No clear seasonal pattern was evidenced, in relation with the measured rainfall and runoff amounts. 
Postprint version of:

Biddoccu et al., 2016. Long-term monitoring of soil management effects on runoff and soil erosion in sloping vineyards in Alto Monferrato (North-West Italy). Soil Till. Res., 155 (2016), pp. 176-189.

https://doi.org/10.1016/j.still.2015.07.005

Table 6. Total nutrients yields measured in the period 2000-2013 (data not available for years 2005 and 2010) from the Cannona Erosion Plots ( $C T$ = conventional tillage; RT (ST) = reduced tillage converted in conventional tillage with grass strip (ST); GC = grass cover). Analyzed nutrients are: ammoniacal nitrogen $\left(\mathrm{NH}_{4}-\mathrm{N}\right)$, nitrates $\left(\mathrm{NO}_{3}-\mathrm{N}\right)$, phosphate $\left(\mathrm{PO}_{4}{ }^{3-}\right)$, Potassium $(\mathrm{K})$.

\begin{tabular}{|c|c|c|c|c|c|c|}
\hline & & Autumn & Winter & Spring & Summer & Total \\
\hline Number of events & & 34 & 9 & 22 & 15 & 80 \\
\hline \multicolumn{2}{|l|}{$P(\mathrm{~mm})$} & 2409.4 & 672.2 & 1348.8 & 505.4 & 4935.8 \\
\hline Runoff & $\mathrm{CT}$ & 446.7 & 250.8 & 401.7 & 43.7 & 1142.9 \\
\hline \multirow[t]{2}{*}{$(\mathrm{mm})$} & $\mathrm{RT}(\mathrm{ST})$ & 415.8 & 140.2 & 153.0 & 22.3 & 731.4 \\
\hline & GC & 567.3 & 196.0 & 346.6 & 66.3 & 1176.3 \\
\hline
\end{tabular}

$\mathrm{NH}_{4}-\mathrm{N}$

$\left(\mathrm{kg} \mathrm{ha}^{-1}\right)$

$\begin{array}{lccccc}\text { CT } & 3.7 & 4.5 & 3.1 & 0.8 & 12.1 \\ \text { RT(ST) } & 4.0 & 1.7 & 1.0 & 0.8 & 7.5 \\ \text { GC } & 3.0 & 0.7 & 0.7 & 0.3 & 4.7\end{array}$

$\mathrm{NO}_{3}-\mathrm{N}$

$\left(\mathrm{kg} \mathrm{ha}^{-1}\right)$

$\begin{array}{lccccc}\text { CT } & 45.2 & 17.6 & 19.2 & 0.3 & 82.3 \\ \text { RT(ST) } & 33.1 & 3.8 & 10.1 & 7.1 & 54.0 \\ \text { GC } & 9.4 & 5.0 & 3.1 & 0.2 & 17.7\end{array}$

$\mathrm{PO}_{4}^{3-}$

$\begin{array}{lllllll}\left(\mathrm{kg} \mathrm{ha}^{-1}\right) & \mathrm{CT} & 0.9 & 3.2 & 0.5 & 0.2 & 4.8 \\ & \mathrm{RT}(\mathrm{ST}) & 1.9 & 0.3 & 1.3 & 0.2 & 3.7 \\ & \mathrm{GC} & 1.2 & 3.8 & 0.5 & 0.4 & 6.0 \\ \mathrm{~K} & & & & & & \\ \left(\mathrm{~kg} \mathrm{ha}^{-1}\right) & \mathrm{CT} & 8.0 & 9.5 & 7.4 & 1.8 & 26.8 \\ & \mathrm{RT}(\mathrm{ST}) & 11.1 & 6.2 & 7.1 & 2.5 & 26.9 \\ & \mathrm{GC} & 7.5 & 3.4 & 3.1 & 2.2 & 16.2 \\ & & & & & & \\ \end{array}$

Potassium (K) losses were very similar in the tilled plots, nearly $40 \%$ greater than in GC plot. The seasonal distribution of the potassium losses was similar to the rainfall/runoff pattern. 
Postprint version of:

Biddoccu et al., 2016. Long-term monitoring of soil management effects on runoff and soil erosion in sloping vineyards in Alto Monferrato (North-West Italy). Soil Till. Res., 155 (2016), pp. 176-189.

https://doi.org/10.1016/j.still.2015.07.005

Indeed, most of the losses in RT and GC were due to runoff events, which occurred in autumn, and to winter precipitation in CT. Potassium losses were the lowest in summer for all treatments.

Most of the nutrient losses, excepted phosphate, occurred during spring and autumn, which coincide with time when they were distributed (only during first 4 years of experimentation) and which were also the most rainy seasons.

\section{Conclusions}

The results of 14-year monitoring in experimental vineyard plots in Piedmont show that runoff and sediment losses, despite high seasonal and inter-annual variability, were concentrated in autumn and, only for soil losses, in summer. Furthermore water and soil losses presented high yearly amounts, which were very often higher than reference values proposed for vineyards in Europe. Regardless the soil management adopted in the interrows, averages for annual sediment losses were greater than the tolerable soil erosion rates proposed for Europe (Verheijen et al., 2009). Overall, the vineyards managed with tillage lost up to $20.7 \mathrm{Mg} \mathrm{ha}^{-1}$ year $^{-1}$. In Piedmont and other Italian regions grass cover of the interrow is one of the most effective and used practices for controlling soil degradation, usually adopted thanks to payments of agricultural subsidies. Nevertheless, vineyards on sloping hillsides or mountainsides are still managed with tillage for mechanical grass removal within the rows. Results show that the soil management adopted in the vineyard inter-rows and the repeated tractor traffic during farming operations have a relevant effect on the soil physical properties, and thus on the runoff and soil erosion processes and their spatial and temporal variability. At yearly scale, and especially over a long-time observation, the grassed vineyard showed lower runoff and soil erosion if compared with tilled plots. The grass cover was especially effective in reducing soil losses during summer months, when very erosive storms usually occur, but its protective effect decreased in autumn, when soil is more compacted and the cover is low. Nutrient losses were also the lowest (except phosphorus) in the plot where grass cover was adopted. Moreover, the results show that the negative effect of adoption of tillage in the inter-rows, rather than grass cover, is particularly evident after some years, as well the degradation (or not) of physical properties of the soil in the vineyard is related to the history of the soil management. In any case, tractor traffic in vineyards has a great influence on the spatial variability of soil properties affecting water infiltration, runoff, and soil erosion processes. The soil and water conservation in the vine- 
Postprint version of:

Biddoccu et al., 2016. Long-term monitoring of soil management effects on runoff and soil erosion in sloping vineyards in Alto Monferrato (North-West Italy). Soil Till. Res., 155 (2016), pp. 176-189.

https://doi.org/10.1016/j.still.2015.07.005

growing systems will be more and more relevant, taking in account climate changes that predict increase in rainfall intensity and erosivity. The results indicate the need of improving conservation measures in order to reduce water and soil losses in vineyards, especially in autumn, which is the season where extraordinary meteorological events have occurred in the Piedmont during the last decades. The results obtained from the Cannona long-term monitoring program could be useful in a multidisciplinary approach to investigate interactions among land use/ soil management and hydrological/sediment transport processes at different scales, raising up from hillslope to small basin scale.

Acknowledgements. This research was funded by the "Centro Sperimentale Vitivinicolo Regionale Tenuta Cannona" and the Regione Piemonte-Office for Agricultural Development and Office for Agricultural Enterprises (research projects titled "Erosione del suolo: confronto tra inerbimento e diverse modalità di lavorazione del terreno, a rittochino e di traverso" and "Tutela del suolo e delle acque superficiali"). The study was partially carried out within the project CIRCE (Cooperative Internet-of-Data Rural-alpine Community Environment), funded by EU FESR, by Italian Government and Regione Piemonte within the programme Regione Piemonte POR/ FESR 2007-2013. This work was partially funded by MIUR-PRIN project 2010JHF437_004. We are very grateful to ARPA Piemonte that provided rainfall data of the Ovada station; to the staff of the "CSV Tenuta Cannona" that managed the vineyards; to Mr. Guarino Benvegnù and Mr. Giorgio Capello who have collaborated in the fieldwork.

\section{References}

Arnaez, J., Lasanta, T., Ruiz-Flaño, P., Ortigosa, L., 2007. Factors affecting runoff and erosion under simulated rainfall in Mediterranean vineyards. Soil Till. Res. 93, 324-334.

Bagarello, V., lovino, M., Elrick, D., 2004. A simplified falling-head technique for rapid determination of field-saturated hydraulic conductivity. Soil Sci. Soc. Am. J. 68, 66-73.

Barthès, B., Roose, E., 2002. Aggregate stability as an indicator of soil susceptibility to runoff and erosion; validation at several levels. Catena 47, 133-149.

Biancotti, A., Bellardone, G., Bovo, S., Cagnazzi, B., Giacomelli, L., Marchisio, C., 1998. Distribuzione Regionale di Piogge e Temperature. Collana Studi Climatologici del Piemonte, Vol.1. Regione Piemonte. Torino. 
Postprint version of:

Biddoccu et al., 2016. Long-term monitoring of soil management effects on runoff and soil erosion in sloping vineyards in Alto Monferrato (North-West Italy). Soil Till. Res., 155 (2016), pp. 176-189.

https://doi.org/10.1016/j.still.2015.07.005

Biddoccu, M., Ferraris, S., Cavallo, E., Opsi, F., Canone, D., Previati, M., 2013. Hillslope Vineyard Rainfall-Runoff Measurements in Relation to Soil Infiltration and Water Content", Procedia Environmental Sciences 19, 351-360.

Biddoccu, M., Opsi, F., Cavallo, E., 2014. Relationships between runoff and soil losses with rainfall characteristics and a long-term soil management practices in a hilly vineyard (Piedmont, NW Italy). Soil Sci. Plant Nutr. 60(1), 92-99. http://dx.doi.org/10.1080/00380768.2013.862488

Blake, G.R., Hartge K.H. 1986. Bulk density, in: A. Klute (Ed.), Methods of Soil Analysis. Part 1. Physical and Mineralogical Methods (2nd ed.), American Society of Agronomy-Soil Science Society of America, Madison, Wisconsin, USA, pp. 363-375.

Blavet, D., De Noni, G., Le Bissonnais, Y., Leonard, M., Maillo, L., Laurent, J.Y., Asseline, J., Leprun, J.C., Arshad, M.A., Roose, E., 2009. Effect of land use and management on the early stages of soil water erosion in French Mediterranean vineyards. Soil Till. Res. 106, 124-136.

Brown, L.C., Foster, G.R., 1987. Storm erosivity using idealized intensity distributions. Transactions of ASAE 30 (2), 379-386.

Carta Geologica d'Italia, scala 1:100.000, Foglio 70.

Casalí, J., Gastesi, R., Álvarez-Mozos, J., De Santisteban, L.M., Lersundi, J.D.V.d., Giménez, R. , Larrañaga, A., Goñi, M., Agirre, U., Campo, M.A., López, J.J., Donézar, M., 2008. Runoff, erosion, and water quality of agricultural watersheds in central Navarre (Spain), Agr.Water Manage. 95, 1111-1128.

Castillo, V.M., Gomez-Plaza, A., Martínez-Mena, M., 2003. The role of antecedent soil water content in the runoff response of semiarid catchments: a simulation approach. J. Hydrol. 284, 114-130.

Cerdan, O., Govers, G., Le Bissonnais, Y., Van Oost, K., Poesen, J., Saby, N., Gobin, A., Vacca, A., Quinton, J., Auerwald, K., Klik, A., Kwaad, F.J.P.M., Raclot, D., Ionita, I., Rejman, J., Rousseva, S., Muxart, T., Roxo, M.J. \& Dostal, T. (2010). Rates and spatial variations of soil erosion in Europe: A study based on erosion plot data. Geomorphology 122, 167-177.

CEC, 2006a. Communication from the Commission to the Council, the European Parliament, the European economic and social Committee and the Committee of the Regions. Thematic Strategy for Soil Protection. Brussels, 22.9.2006, COM(2006) 231 final. 
Postprint version of:

Biddoccu et al., 2016. Long-term monitoring of soil management effects on runoff and soil erosion in sloping vineyards in Alto Monferrato (North-West Italy). Soil Till. Res., 155 (2016), pp. 176-189.

https://doi.org/10.1016/j.still.2015.07.005

CEC, 2006b. Proposal for a directive of the European Parliament and of the Council establishing a framework for the protection of soil and amending Directive 2004/35/EC. Brussels, 22.9.2006, COM(2006) 232 final.

Corti, G., Cavallo, E., Cocco, S., Biddoccu, M., Brecciaroli, G., Agnelli, A., 2011. Evaluation of Erosion Intensity and Some of Its Consequences in Vineyards from Two Hilly Environments Under a Mediterranean Type of Climate, Italy, in Godone, D., Stanchi, S. (Eds.), Soil Erosion Issues in Agriculture, InTech, pp. 113-160.

Costantini, E.A.C., Lorenzetti, R., 2013. Soil degradation processes in the Italian agricultural and forest ecosystems. Italian Journal of Agronomy, volume 8:e28.

EC, 2006. Directive 2000/60/EC of the European Parliament and of the Council of 23 October 2000 establishing a framework for Community action in the field of water policy. Official Journal of the European Communities, 22.12.2000.

Elrick, D.E., Reynolds, W.D., 1992a. Methods for analyzing constant-head well permeameter data. Soil Sci. Soc. Am. J., 56, 320-323.

Elrick, D.E., Reynolds, W.D., 1992b. Infiltration from constant-head well permeameter and infiltrometers, in: Topp, G.C., Reynolds, W.D., Green, R.E (Eds.), Advanced in Measurement of Soil Physical Properties: Bringing Theory into Practice. Special Pubblication no. 30, American Society of Agronomy, Madison, WI, pp. 1-24.

FAO/ISRIC/ISSS, 1998. World Reference Base for Soil Resources. World Soil Resources Report, No 84. FAO, Rome

Ferrero, A., Usowicz, B., Lipiec, J., 2005. Effects of tractor traffic on spatial variability of soil strength and water content in grass covered and cultivated sloping vineyard. Soil Till. Res. 84, 127-138.

Gomez, J.A., Vanwallenghem, T., De Hoces, A., Taguas, E.V., 2014. Hydrological and erosive response of a small catchement under olive cultivation in a vertic soil during a fiveyear period: Implications for sustainability. Agr. Ecosyst. Environ. 188, 229-244.

Hajabbasi, M.A., Hemmat, A., 2000. Tillage impacts on aggregate stability and crop productivity in a clay-loam soil in central Iran. Soil Till. Res. 56, 205-212. 
Postprint version of:

Biddoccu et al., 2016. Long-term monitoring of soil management effects on runoff and soil erosion in sloping vineyards in Alto Monferrato (North-West Italy). Soil Till. Res., 155 (2016), pp. 176-189.

https://doi.org/10.1016/j.still.2015.07.005

IPLA, 2007. Carta dell'erodibilità dei suoli. Available from: http://www.regione.piemonte.it/agri/suoli_terreni/dwd/atla_carto250/piem_erod_250.pdf. Last accessed on 06.11.2014

ISTAT, 2014. Superficie e produzioni. Available on: http.//www.istat.it/it/agricoltura-ezootecnia Last Accessed on 06.11.2014.

Leonard, J., Andrieux, P., 1998. Infiltration characteristics of soils in Mediterranean vineyards in Southern France. Catena 32, 209-223.

Maetens, W., Vamaercke, M., Poesen, J., Jankauskas, B., Jankauskiene, G., Ionita, I., 2012. Effect of land use on annual runoff and soil loss in Europe and the Mediterranean: A metaanlysis of plot data. Prog. Phys. Geog. 36 (5), 599-653.

MiPAF, 2015. Rete Agrometeorologica Nazionale. https://www.politicheagricole.it/flex/FixedPages/Common/miepfy200 reteAgrometeorologic a.php/L/IT Last Accessed on 09.07.2015.

MiPAF, 2014. Banca Dati Agrometeorologica Nazionale. http://cma.entecra.it/Banca_dati_agrometeo/index3.htm

Last Accessed on 06.11.2014.

Morgan, R.P.C., 2005. Soil Erosion and Conservation, 3rd ed. Blackwell Publishing, 304 pp. Novara, A., Gristina, L., Saladino, S.S., Santoro, A., Cerdà, A. 2011. Soil erosion assessment on tillage and alternative soil managements in a Sicilian Vineyard. Soil Till. Res. $117,140-147$.

Opsi, F., Biddoccu, M., Cavallo, E., 2012. Effect of soil management and tractor traffic on the long-term assessment of sloping vineyard soil compaction. Proceedings of "The Fourth International Congress on viticulture in mountain", Lyon (France), 7-9 November 2012.

Raclot, D., Le Bissonais, Y., Louchart, Y., Andrieux, P., Moussa, R., Voltz, M., 2009. Soil tillage and scale effects on erosion from fields to catchment in a Mediterranean vineyard area. Agr. Ecosyst. Environ., Catena 66, 198-210.

Ramos, M.A., Martínez-Casasnovas, J.A., 2010. Soil water balance in rainfed vineyards of the Penedès region (Northeastern Spain) affected by rainfall characteristics and land levelling: influence on grape yield. Plant Soil 333, 375-389. 
Postprint version of:

Biddoccu et al., 2016. Long-term monitoring of soil management effects on runoff and soil erosion in sloping vineyards in Alto Monferrato (North-West Italy). Soil Till. Res., 155 (2016), pp. 176-189.

https://doi.org/10.1016/j.still.2015.07.005

Regione Piemonte, 2014a. Superfici per le principali forme di utilizzazione del terreno e per comune del centro aziendale (Censimento agricoltura 2010). Available on: http://www.sistemapiemonte.it/censagile/home.do Last Accessed on 06.11.2014

Regione Piemonte, 2014ab. Banca Dati Agrometeo. http://www.sistemapiemonte.it/cms/privati/agricoltura/servizi/378-ram-banca-datiagrometeorologica-consultazione-dati-giornalieri-dati-storici-statistiche Last Accessed on 06.11.2014.

Ruiz-Colmenero, M., Bienes, R., Marques, M.J., 2011. Soil and water conservation dilemmas associated with the use of green cover in steep vineyards. Soil Till. Res. 117, 211-223.

Soil Survey Staff, 2010. Keys to Soil Taxonomy. 11th ed. Washington, DC: USDA-Natural Resources Conservation Service.

Topp, G. C., Davis, J. L., Annan, A. P., 1980. Electromagnetic determination of soil water content: measurements in coaxial transmission lines, Water Resour. Res. 16(3), 574-582.

Tropeano, D., 1984. Rate of soil erosion processes on vineyards in Central Piedmont (NW Italy). Earth Surf. Proc. Land. 9, 253-266.

van der Knijff, J.M., Jones, R.J.A. \& Montanarella, L., 2000. Soil erosion risk assessment in Italy. European Soil Bureau, Office for Official Publications of the European Communities, Luxemburg.

Verheijen, F.G.A. , Jones, R.J.A., Rickson, R.J. et al., 2009. Tolerable versus actual soil erosion rates in Europe. Earth-Sci. Rev. 94, 23-38.

Walczak, R., Orlowsky, R., Pukos, A., 1973. A manual spring penetrometer of soil with a recorder. Polish Journal of Soil Science 2, 87-94.

Wischmeier, W.H., Smith., D.D., 1978. Predicting Rainfall Erosion Losses: A Guide to Conservation Planning. Agriculture Handbook No. 537. USDA/Science and Education Administration, US. Govt. Printing Office, Washington, DC. 